\title{
The Jacksonian Makings of the Taney Court
}

Daniel Webster in 1841 warned Whig associates that the Supreme Court was likely to declare unconstitutional the national bank bill that Henry Clay was pushing through the Congress. ${ }^{1}$ This claim was probably based on inside information. Webster was a close associate of Justice Joseph Story, and justices at this time frequently leaked word to their political allies of judicial sentiments on the issues of the day. ${ }^{2}$ Even if Webster lacked first hand knowledge of

\footnotetext{
${ }^{1}$ Merrill D. Peterson, The Great Triumvirate: Webster, Clay, and Calhoun (Oxford University Press: New York, 1987), p. 306. See National Intelligencer 6/15-17; Webster Papers, 2 Mangum Papers, pp., 182-83. See also, Swisher, Taney Years, p. 29 (quoting Leslie Combs to Nicholas Biddle, July 27, 1835) ("Genl. J. says the Bk is unconstitutional. Mr. Van Buren echoes the opinion and old Tecumseh [probably Richard Johnson] follows suit. Will the Judges--his officers, dare to decide otherwise by \& bye").

${ }^{2}$ See Swisher, Roger Taney, p. 564; Silver; White. For the Story/Webster relationship, see __ ; Swisher, Roger Taney, pp. 201-202, 258-59 (noting that Story routinely advised Webster on constitutional issues in American politics). The most famous leak of judicial sentiments occurred when Justice Catron, with the permission of Chief Justice Taney Justice Grier and Justice Wayne, kept President-elect Buchanan informed of the judicial deliberations in the Dred Scott case. See Auchumpaugh FIND; Warren, 2 The Supreme Court, pp. 295-96; Swisher, Taney Years, pp. 615-18; Swisher, Roger Taney, pp. 495-96, 498-01. Chief Justice Taney may have also privately discussed how to resolve that case with Attorney General Caleb
} 
how the Taney Court would probably rule in a case raising the constitutionality of the national bank, his knowledge of the personnel on that tribunal provided strong grounds for Whig pessimism. Jacksonian politics, the Jacksonian politics of judicial selection, and the politics of the Jacksonians on the federal bench gave good reason for supposing that Taney Court majorities would be hostile to a national bank and to any other prominent Whig initiative thought to be grounded in a "latitudinous" construction of federal power. Most Jacksonians vigorously opposed the national bank on both policy and constitutional grounds. The most vigorous opponents of that institution had been appointed to the Taney Court. The partisan activities of these justices while on the federal bench gave little reason for hope that Taney Court majorities would separate law from politics when deciding a case raising those constitutional questions that divided their Jacksonian sponsors from their Whig rivals.

Webster's fear that McCulloch was in imminent danger of being overruled or substantially narrowed suggested earlier Whig fears had been alleviated, that the Supreme Court would not abandon judicial power altogether. The Taney Court's first decisions, ${ }^{3}$ combined with much anti-judicial rhetoric in Congress and state legislatures during the 1820s by politicians

Cushing. Swisher, Roger Taney, p. 500. McLean may have leaded information about judicial deliberations to his political supporters. Swisher, Roger Taney, pp. 489.

${ }^{3}$ See Charles River Bridge Co. v. Warren Bridge Co., 36 U.S. 420 (1837); Mayor v. Miln, 36

U.S. 102 (1837); Briscoe v. Bank of the Commonwealth of Kentucky, 36 U.S. 257 (1837), discussed above, pp. 
closely identified with the Jacksonian revolution, ${ }^{4}$ fostered impressions that a Jacksonian bench would in the name of democratic majoritarianism routinely sustain any federal or state law under constitutional attack. Proponents of a strong federal judiciary were convinced that Martin v. Hunter's Lessee $^{5}$ and other precedents supporting judicial review of state legislation would shortly be overruled. Even Marbury v. Madison seemed practically doomed in the long run. ”There will not, I fear,” Justice Story wrote Justice McLean in 1837, “ever in our day, be any case in which a law of a State or of Congress will be declared unconstitutional.”6 Influenced by Story’s understanding of Jacksonian politics, twentieth century commentators have seen the subsequent willingness of Taney Court majorities to declare laws unconstitutional as proof that the justices on that tribunal abjured Jacksonian partisanship upon taking the bench. Charles Warren, in particular, insisted that the judicial willingness to impose contract clause, commerce clause and other constitutional limitations on the powers of state governments demonstrated the continued vitality of a healthy separation of law and politics on the antebellum judiciary. ${ }^{7}$ Webster's adjusted understanding of Jacksonian politics varies the body of the argument for judicial independence, but not, apparently, the punchline. The Massachusetts Senator feared that the Jacksonian dominated Taney Court would exercise judicial

\footnotetext{
${ }^{4}$ Longaker, pp. 341-42.

514 U.S. 304 (1816).

${ }^{6}$ Justice Story to Justice McLean, May 10, 1837, p. 272

${ }^{7}$ See footnote above.
} 
power with gusto, declaring unconstitutional such vital Whig initiatives as the national bank.

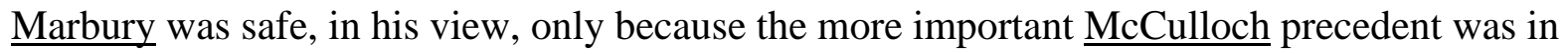
jeopardy. From this Websterian perspective, therefore, the Taney Court's failure to declare certain limits on federal power better demonstrates that tribunal's capacity to separate constitutional law from partisan politics than various decisions declaring state laws unconstiutional.

Webster's judicial fears had better political grounding that Story’s concerns. By the time Jacksonians had established firm control over the federal judiciary, Whigs had far more reason to worry that the justices would strike down controversial exercises of national power than abandon judicial review. Political coalitions that vigorously attack judicial review when out of power have often become enthusiastic devotees of that practice when in power. Why, after all, should astute politicians maintain that a branch of government controlled by their coalition is duty bound to sustain all policies made by other political institutions, some of which may be controlled by rival forces? ${ }^{8}$ Jacksonians proved no exception to this historical tendency. As

\footnotetext{
${ }^{8}$ See William Lasser, The Limits of Judicial Power: The Supreme Court in American Politics (University of North Carolina Press: Chapel Hill, 1988). Many New Dealers after 1937 began insisting that civil rights and civil liberties issues were important exceptions to the general principle that justices should not interfere with legislative policymaking. See United States v. Carolene Products Co., 304 U.S. 144, 152-53 n.4 (1938); Mark A. Graber; Transforming Free Speech: The Ambiguous Legacy of Civil Libertarianism (University of California Press:
} Berkeley, 1991), pp. 151-59; Martin Shapiro, “The Supreme Court: From Warren to Burger,” 
early as 1830, President Jackson and many prominent supporters were articulating pro-judicial sentiments. This pro-judicial strand in Jacksonian rhetoric became stronger as Jacksonian jurists increasingly dominated the federal bench. By the 1850s, prominent Jacksonians were looking to expand the jurisdiction of federal courts and enthusiastically championing judicial supremcy. The judicial selection process in the three decades before the Civil War further demonstrates Jacksonian support for judicial review. Most of the justices on the Taney Court had publicly defended the judicial power to declare laws unconstitutional before being appointed to the federal bench. With the notable exception of Philip Pendleton Barbour, no Jacksonian judicial nominee was associated with the political attacks made on the federal judiciary during the debates over whether to repeal Section 25 of the Judiciary Act of 1789, the statutory provision that licensed most judicial review of state legislation. The continued survival of Marbury,

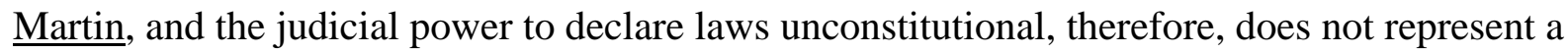
triumph of law over politics.

The willingness of Taney Court justices to declare particular state laws unconstitutional similarly represents no triumph of law over politics. Jacksonians insisted that the power of the federal government was limited, but were equally insistent that the federal government was supreme within those limits. State rights did not extend to nullification or personal liberty laws. Indeed, Jacksonian proposals for expanding the jurisdiction of federal courts were intended to

The New American Political System (edited by Anthony King) (American Enterprise Institute: Washington, D.C., 1978), pp. 192-93. Ronald Reagan’s judicial appointees exhibit far more deference to legislative regulations of abortion than legislation mandating affirmative action. See Klarman. 
ensure that local actors did not unconstitutionally interfere with the exercise of legitimate national powers over the tariff and slavery. Leading Jacksonians also exhibited no rigid preference for state power on constitutional matters that did not directly involve limiting federal power. Opinions in antebellum America on the proper scope of such provisions as the contracts clause almost always depended more on the particular interests involved in the case before the court than on the depth of any previous commitments to state rights. Jacksonians appointed to the supreme court had similarly exhibited no rigid preference for state rights when no corresponding limit on federal power was involved. Jacksonian judicial nominees before joining the federal bench had uniformly demonstrated strong public support for Jackson’s militantly nationalistic, anti-state rights positions and proposals during the nullification crisis. None had publicly championed lifting or narrowly interpreting all the constitutional prohibitions on state power set out in Article I, Section 10. Barbour was the only justice who in his previous political incarnation consistently supported the state rights positions on constitutional issues that did not raise questions of federal power.

The Taney Court's apparent failure to declare federal laws unconstitutional, however, does seemingly represent both a major triumph of law over politics and a dramatic refutation, at least as applied to the antebellum judiciary, of the attitudinal model of judicial decisionmaking. Jacksonian executives and legislative leaders repeatedly declared that Congress had no power to incorporate a national bank, enact a general system of internal improvements, or distribute surplus revenue from land sales to the states. Prospective judicial appointments were carefully scrutinized to ensure fidelity to these goals. By 1837, a judicial majority was in place on public record as opposed most elements of the American System. Moreover, that opposition had 
frequently been expressed on constitutional grounds. Any expectation that Jacksonians on the federal bench might nevertheless disappoint their Jacksonian political sponsors seemed particularly unrealistic. No Supreme Court in American history was staffed with justices less likely to separate law and politics. Most Taney Court justices had played active roles in Jacksonian politics before their judicial appointments and most continued their partisan activities with varying degrees of discreteness while on the federal bench. That McCulloch was still intact when Lincoln took office in 1861 seems the most powerful demonstration in American history of the judicial capacity to cast off previous partisan dispositions and decide cases strictly according to law.

\section{A. Jacksonian Commitments and Judicial Selection}

The Taney Court was a Jacksonian tribunal. Twelve of the sixteen justices who sat on that bench for at least five years were appointed by Jacksonian executives. The thirteenth was appointed by John Tyler, a pseudo-Whig whose constitutional views on national power were far closer to those of Andrew Jackson than Henry Clay. ${ }^{9}$ Jacksonian executives, at least after $1830,{ }^{10}$ carefully scrutinized their judicial nominees to ensure fidelity to Jacksonian understandings of federal power. President Jackson, Henry Abraham’s classic study of the judicial appointment process notes, clearly demonstrated "that political loyalty would have

\footnotetext{
${ }^{9}$ FIND

${ }^{10}$ See PP. _ , below.
} 
primacy in his decisions" and "was determined to reward the party faithful."11 Jackson in 1834 informed Martin van Buren that only jurists whose “principles on the Constitution are sound, and well fixed" would be considered for Supreme Court nominations. ${ }^{12}$ Concerned that Marshall Court justices were "broadly Federal and latitudinarian in all their decisions involving questions of Constitutional power,” President Polk “resolved to appoint no man who was not an original Democrat and strict constructionist, and who would be less likely to relapse into the broad Federal doctrines of Judge Marshall and Judge Story."13 President Tyler insisted that "no one should be appointed who was of the school of Story and Kent.”14

${ }^{11}$ Abraham, Justices and Presidents, p. 96. See Abraham, Justices and Presidents, p. 103 (noting that "Jackson was not overridingly concerned” with whether his candidates had a judicial background).

${ }^{12}$ Longaker, p. 358 n.43 (quoting Andrew Jackson to Martin Van Buren, October 27. 1834).

13 James K. Polk, Polk: The Diary of a President 1845-1849 (edited by Allan Nevins) (Longmans, Green and Co.: London, 1929), p. 37. See Charles Grove Sellers, Jr., James K. Polk: Continentalist 1843-46 (Princeton University Press: Princeton, 1966), p. 298.

${ }^{14}$ William Wetmore Story, The Life and Letters of Joseph Story (Vol II) (Books for Libraries Press: Freeport, New York, 1971), p. 523. See Henry J. Abraham, Justices and Presidents: A Political History of Appointments to the Supreme Court (third edition) (Oxford University Press: New York, 1992), p. 96; Swisher, Roger Taney, p. 426, 428 (noting that Van Buren sought to ensure that prospective justices were "Democrat[s] and would stick to the true principles of the 
Polk’s concern with justices who were "broadly Federal and latitudinarian in all their decisions involving questions of Constitution power” highlights two relatively unappreciated elements of mature Jacksonianism that during the three decades before the Civil War influenced the judicial selection process and Taney Court decisionmaking. First, Jacksonian executives were not hostile to judicial power per se. The main problem with justices "broadly Federal and latitudinarian” was their willingness to sustain controversial exercises of federal power. The

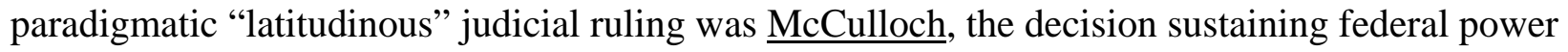
to incorporate a national bank. Second, Jacksonian executives were more concerned with limiting Federal power than with advancing a more general state rights agenda. Jacksonians did advance state rights when insisting that the Constitution entrusted most important governmental functions to the states. Still, the concern with "broadly Federal and latitudinarian" construction suggests that expanding the power of states per se was less a central Jacksonian commitment than limiting federal power. In particular, Jacksonians as a political coalition (as opposed to particular Jacksonians) do not appear to have been concerned with two state rights issues that did not involve corresponding limits on federal power: issues concerned federal exclusivity, whether the mere existence of legitimate federal power automatically barred state regulation even when the federal government had chosen not to exercise that power, and issues concerning the scope of

Constitution”). Other Jacksonians urged similar judicial nomination strategies. See Swisher,

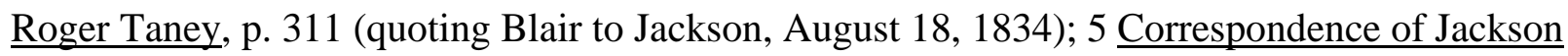
FIND.

Millard Fillmore, by comparison, sought to pack the judicial with committed Whigs. See Swisher. Roger Taney, p. 445 (quoting Fillmore to Webster, September 10, 1851). 
such Article I, Section 10 constitutional restrictions on state governmental power as the contracts clause, restrictions that existed independently of federal power.

The Jacksonian coalition was also not committed to a strict construction, anti-federal power position on all issues of the day. The Force Bill of 1833, the Mexican War, the annexation of Texas, the Fugitive Slave Act of 1850 and efforts to acquire Cuba all demonstrate that Jacksonians in appropriate circumstances would exercise national powers in ways their political opponents thought unconstitutional. Contrary to the numerous Whigs who had constitutional scruples about the Mexican War, ${ }^{15}$ the Democratic Platform of 1848 insisted that "it is the duty of the country to sustain the administration in every measure necessary to provide for the vigorous prosecution of the war."16 Contrary to those Free Soilers and Republicans who believed that the federal government had no power to return escaped slaves, ${ }^{17}$ the Democratic party platforms in 1852 and 1856 asserted that the fugitive slave act of 1850, "being designed to carry out an express provision of the constitution cannot, with fidelity thereto be repealed nor so

${ }^{15}$ See McLean; Lincoln

${ }^{16}$ National Party Platforms, p. 11. See National Party Platforms, pp. 11, 17 (declaring the conflict to be “a just and necessary war on our part”).

${ }^{17}$ See party platforms. Not all Republicans condemned the Fugitive Slave Law of 1850 on constitutional grounds. Lincoln, in particular, defended constitutional power to pass such measures. FIND 
changed as to destroy or impair its efficiency."18

Orthodox Jacksonians were nationalists who believed that most ordinary functions of government were constitutionally entrusted to the states. Few antebellum Democrats accepted the Calhounian heresy that the federal government was subordinate to the states in all functions. Jacksonian opposition to nullification in the South and personal liberty laws in the north demonstrate that its constitutional preference for state action did not extend to state action that interfered with what Jacksonians believed were legitimate functions of the federal government. Such Jacksonian judicial nominees as McKinley, Barbour, Wayne and Catron had before joining the bench distinguished themselves in both the war against the national bank and in defense of Jackson during the nullification crisis. ${ }^{19}$ Grier was a strong proponent of the federal power to assist with the recapture of fugitive slaves. ${ }^{20}$ This strand of Jacksonian nationalism may help explain why the two southern Jacksonians appointed to the Supreme Court in the wake of the nullification crisis, Catron and Wayne, did not resign their seats after 1861 when their home state

${ }^{18}$ National Party Platform, pp. 17, 25.

${ }^{19}$ Frank Otto Gatell, “Philip Pendleton Barbour,” The Justices of the United States Supreme Court 1789-1978: Their Lives and Major Opinions (Volume I) (edited by Leon Friedman and Fred L. Israel) (Chelsea House Publishers: New York, 1980), p. 724; John M. Martin, "John McKinley: Jacksonian Phase," 28 Alabama Historical Quarterly 7 (1966); Swisher, Roger Taney, p. 311.

${ }^{20}$ FIND 
seceded.

The following examination of Jacksonian political commitments and the making of the Taney Court demonstrates why when measuring the influence of partisanship on judicial decisionmaking, scholars should not blithely assume that Jacksonians automatically supported the state rights position, ${ }^{21}$ that any anti-state vote demonstrates judicial independence and the separation of law from politics. The extent to which the Taney Court decisions supported or rejected orthodox Jacksonian policies can be determined only when orthodox Jacksonian policies are characterized with more sophistication than is often the case in studies of judicial policymaking. No necessary differences existed between prominent strands of Jacksonian thought and orthodox Whig positions on such issues as the exclusivity of certain federal powers and the scope of federal judicial authority. Differences existed on questions of federal power, but as various partisan responses to the Mexican War demonstrate, those differences are not fully captured by a model that only considers broad versus narrow constriction of federal power. Scholars who fail to make these fine distinctions risk labeling Levi Woodbury as "stanchly Hamiltonian,”22 apparently unaware that before joining the bench Woodbury helped write Jackson’s message vetoing the national bank and, as Van Buren secretary of the treasury, played a leading role formulating Jacksonian financial policies.

\footnotetext{
${ }^{21}$ For an example of this mistake, see Segal and Spaeth, The Supreme Court, pp. 82-83. See also, Abraham, Justices and Presidents, p. 99.

${ }^{22}$ Segal and Spaeth, The Supreme Court, p. 82.
} 


\section{Judicial Power}

Jacksonians in power exhibited no general hostility to judicial power. Democratic party platforms never took a position or even mentioned those questions of federal jurisdiction that provoked intense debate during the 1820s. One would not even know from reading Democratic party platforms that a federal judiciary existed until 1860, when the platform asserted that "the Democratic party will abide by the decision of the Supreme Court of the United States upon ... questions of Constitutional law" concerning the status of slavery in the territories. ${ }^{23}$

President Jackson vigorously opposed particular judicial decisions, most notably judicial decision favoring Cherokee claims, but did not oppose judicial review as a practice. “(A)ll the rights secured to the citizens under the constitution,” he declared before becoming president, are “worth nothing, and a mere babble, except as guaranteed to them . . . by an independent and virtuous Judiciary.”24 The leading study of Jackson’s attitude towards the Supreme Court concludes that " $[\mathrm{t}]$ here is no evidence that the President shared the extreme hostility of many of his lieutenants" towards the federal judiciary, "and at no time did he cooperate with their proposals for drastic judicial reform.”25 Even Jackson’s veto of the national bank bill did not necessarily represent a denial of judicial supremacy. Taney later insisted the veto message

\footnotetext{
${ }^{23}$ National Party Platforms, p. 31.
}

${ }^{24}$ Ellis 1987, p. 32 (quoting Jackson to Andrew Donelson, July 5, 1822, October 11, 1822).

${ }^{25}$ Longaker, p. 342. See Longaker, p. 363. 
merely articulated a presidential prerogative to make independent constitutional judgments when considering whether to sign legislative measures, that Jackson recognized his presidential obligation to enforce any existing law deemed constitutional by the federal judiciary. ${ }^{26}$

Jacksonian presidents articulated increased support for the federal judiciary as that branch of government became dominated by Jacksonian appointees. During the nullification crisis, Jackson urged South Carolina to litigate whether the protective tariff was constitutional and successfully fought to expand the jurisdiction of federal courts in the wake of that crisis. ${ }^{27}$ Pierce; President Buchanan insisted that "the Supreme Court and the Executive branch should stand shoulder to shoulder ...., that united they might be able to resist the fanaticism of both the

${ }^{26}$ Longaker, p. 352 (quoting Taney to Martin Van Buren, June 20, 1860). See Longaker, pp. 352-53 (noting difference interpretation of Jackson's veto, but suggesting that Taney probably expressed the correct understanding); Swisher, Roger Taney, pp. 196-97. Taney expressed a similar view when Attorney General, declaring with respect to the right of states to prohibit free persons of color that although "the judgment pronounced by the court be conclusive it does not follow that the reasoning or principles which it announces in coming to its conclusion are equally binding and obligatory.” Swisher, Roger Taney, p. 157 (quoting Taney). In short, judicial decisions must be obeyed, but elected officials should use their own judgments on questions not explicitly decided by the court.

${ }^{27}$ Ellis 1987, p. 94; Longaker, pp. 358, 360-61. 
North and South."28

When Jacksonian presidents disapproved of specific judicial decisions, they typically sought to achieve more favorable results by using normal political channels. President Jackson may have been unwilling to enforce the judicial decision in Worcester v. Georgia, but Jacksonians in practice settled the case to prevent a clash between the federal executive and federal judiciary that might have weakened judicial capacity to enforce Jackson’s anti-

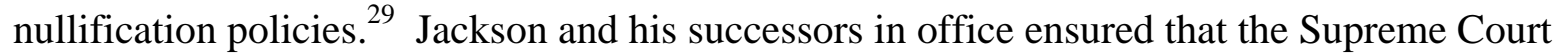
would not further interfere with the removal of the Cherokees and other Native American tribes by subsequently appointing committed proponents of the Jacksonian removal policy to the federal bench. ${ }^{30}$ President Van Buren responded to an unwanted judicial decision holding that the Supreme Court had the power to issue writs of mandamus to cabinet officials ${ }^{31}$ by asking Congress to consider repealing the offending statute. ${ }^{32}$

Jacksonians in the national legislature and states also became increasingly supportive of federal judicial power as Jacksonians took control of the federal bench. Prominent Jacksonians

${ }^{28} 5$ Richardson 553-54 FIND. See Swisher, Taney Period, pp. 666, 670-71.

${ }^{29}$ See Ellis 1987.

${ }^{30}$ See Ellis 1987. p. 32.

${ }^{31}$ Kendall v. United States, 12 Pet. 524.

${ }^{32}$ See Warren, 2 Supreme Court, pp. 48-49; Swisher, Taney Period, p. 164. 
had fought to limit the power of the Supreme Court during the $1820 \mathrm{~s},{ }^{33}$ but by the Jackson presidency opposition to the court per se was largely limited to the South. An 1831 effort to repeal Section 25 was defeated in the House of Representatives by almost a 3-1 margin, with only 6 representatives from free states favoring the bill. ${ }^{34}$ James Buchanan, a future Jacksonian president also offered a seat on the court, wrote the committee report that played a vital role defeating that measure. ${ }^{35}$ When Roger Taney became Chief Justice and a Jacksonian majority formed on the Supreme Court, all significant national efforts to limit the jurisdiction of the Supreme Court ceased. Lewis Cass, the Democratic candidate for the presidency in 1848 was one of many Jacksonians who became a judicial supremacist, proclaiming that "it is a great moral spectacle to see the decrees of the Judges of our Supreme Court on the most vital questions obeyed in such a country as this." Senator Thomas Ewing of Ohio similarly "look[ed] to the Supreme Court as the palladium of our institutions and as one of the brightest and purest ornaments of our system." ${ }^{36}$ After 1836, the only Jacksonian protests against section 25 came

${ }^{33}$ Martin Van Buren during the 1820s fought on the other side, to curtail judicial power to declare state laws unconstitutional. See Warren, “Legislative and Judicial Attacks,” pp. 27, 31.

${ }^{34}$ Warren, “Legislative and Judicial Attacks,” p. 164.

${ }^{35}$ See Charles Warren, "Legislative and Judicial Attacks on the Supreme Court of the United States-A History of the Twenty-Fifth Section of the Judiciary Act,” 47 American Law Review 161, 164 (1913).

36 33-2-298; Swisher, Taney Period, pp. 151, 217. See Swisher, Roger Taney, p. 501 (quoting 
from particular states whose laws had recently been declared unconstitutional. ${ }^{37}$ Attacks on federal judicial supremacy during the 1850s were generally delivered by Northern Republicans attempting to protect free state judicial power over alleged fugitive slaves. ${ }^{38}$ Southern Jacksonians by that time had become particularly strong supporters of judicial review, passing legislation facilitating judicial resolution of the status of slavery in the territories. ${ }^{39}$ Northern Democrats even defended judicial supremacy in the wake of the Dred Scott decision. ${ }^{40}$ The prototype for Reconstruction measures expanding the jurisdiction of federal courts after the Civil War was first introduced in the Congress by Jacksonians during the 1850s as a means for obtaining federal jurisdiction over persons accused of obstructing the recapture of fugitive

Caleb Cushing, Attorney General during the Pierce Administration) (“[a]s the supreme appellate tribunal of the country," the Supreme Court "possess[es] . . . loyal acquiescence in [its] judgments".... [O]ur country looks with undoubting confidence" to the Court "as the interpreters and the guardians of the organic laws of the Union”).

${ }^{37}$ Warren, “Legislative and Judicial Attacks,” pp. 176-85; Warren 2 Supreme Court, p. 150.

${ }^{38}$ Find warren; Swisher, Taney Period, pp. 650, 661-69; Swisher, Roger Taney, p. 527.

39 33-2-240-46; Warren, 2 Supreme Court, p. 264; Swisher, Taney Period, pp. 173, 208-212, 216-17, 221, 268, 590-91, 684.

${ }^{40}$ Douglas; Warren, 2 Supreme Court, p. 329. 
slaves. $^{41}$

Jacksonian judicial appointees were generally committed to judicial power. Many Taney Court justices had maintained before joining the bench that the judiciary was vested with authority to declare laws unconstitutional before, and others made similar claims while on the bench. Levi Woodbury while on the New Hampshire state bench in the 1810s endorsed both judicial review and judicial supremacy when declaring a state law unconstitutional. ${ }^{42}$ Justice Wayne as a state legislator vigorously opposed a Georgia resolution denying federal judicial power to declare laws unconstitutional. ${ }^{43}$ John Catron declared many state laws unconstitutional as a state judge, indicated that substantial constitutional limits existed on federal power, and explicitly affirmed the power of the federal judiciary to declare laws unconstitutional in a letter written to Andrew Jackson several years before his appointment to the Supreme Bench. ${ }^{44}$ Taney regarded judicial decisions as "conclusive" of the case before the Court and may have helped draft the portion of President Jackson’s “Farewell Address” that asserted a state obligation to

${ }^{41}$ Warren, 2 Supreme Court, p. 264.

${ }^{42}$ Levi Woodbury, Writings of Levi Woodbury: Political, Judicial and Literary (Vol. II) (edited by Charles L. Woodbury) (Little, Brown and Company: Boston, 1852), pp. 333-34, 344.

${ }^{43}$ Lawrence, Wayne, pp. 26-27.

${ }^{44}$ FIND. See Edmund C. Gass, "The Constitutional Opinions of Justice John Catron," 8 East Tennessee Historical Society's Publications 54 (1936). 
obey all federal laws until they were repealed or voided by a federal court. ${ }^{45}$ Both John Connor Campbell and Philip Barbour as lawyers urged the Supreme Court to declare federal laws unconstitutional in circumstances which strongly suggest that were advancing personal opinions. Jacksonian appointees to other legal positions shared this commitment to federal judicial power. Senator Hayne of South Carolina vigorously complained when President Jackson appointed a United States attorney who "acknowledge[d] the supremacy of the federal Judiciary over the Judicial tribunals of the State.”46

Philip Pendleton Barbour was the only Taney Court justice who played a major role in efforts to repeal Section 25 of the Judiciary Act, ${ }^{47}$ the section that gave federal courts jurisdiction to hear appeals from state court decisions (Taney seems to have been opposed to that endeavor $^{48}$ ). Representing Virginia before the Supreme Court, Barbour insisted that the Court should rule that Congress had no power to give the Supreme Court jurisdiction to overturn state

45 Swisher, Roger Taney, p. 157,335. FIND

${ }^{46}$ Ellis 1987, p. 49.

${ }^{47}$ See Charles Warren, “Legislative and Judicial Attacks on the Supreme Court of the United States-A History of the Twenty-Fifth Section of the Judiciary Act,” 47 American Law Review 1, 17 (1913). See Warren, “Legislative and Judicial Attacks,” p. 33 (noting Barbour also proposed a bill requiring supra-judicial majorities to declare state laws unconstitutional); Swisher, Taney Period, p. 56.

${ }^{48}$ Longaker, p. 363. 
criminal convictions. ${ }^{49}$ Still, Barbour's participation in Cohens v. Virginia and his frequent demands for limits on federal power highlight an important distinction radical Jacksonians made when discussing federal judicial authority. Justice Holmes famously declared that while no harm would come from denying the supreme court the power to declare federal laws unconstitutional, the Union would fall apart if the justices lacked the power to declare state laws unconstitutional. ${ }^{50}$ Jacksonian radicals inverted this proposition. Jacksonian opponents of the court concentrated their fire of section 25 of the Judiciary Act of 1787, the provision that enabled the Supreme Court to declare state laws unconstitutional. The most prominent opponents of judicial review during the 1820s intended to divest jurisdiction "[i]n all cases where a State shall be a party, and in all controversies in which a State may desire to become a party in consequence of having the Constitution or laws of such State questioned" (emphasis added).$^{51}$ No serious legislative effort was made to limit federal judicial power over national laws. Indeed, Jacksonian attacks on the Court frequently condemned that tribunal for not declaring such federal laws as

${ }^{49}$ FIND. See Gatell, “Barbour,: pp. 721-22; Swisher, Taney Period, p. 56.

${ }^{50}$ FIND

${ }^{51}$ 17-1-23 (speech of Richard M. Johnson). See Warren, “Legislative and Judicial Attacks,” pp. 3-4, 10-12, 15-19, 26-28, 30-33, 161-64, 166-69, 175-76, 181-85. Some proposals to require supramajorities for judicial decisions included both federal and state matters (Warren, “Legislative and Judicial Attacks,” pp. 22, 27, 32), others did not. Warren, “Legislative and Judicial Attacks,” pp. 30-33. 
the incorporation of the national bank unconstitutional. ${ }^{52}$ Spencer Roane, for example, vigorously supported judicial review of federal legislation. He and other old Republicans objected to McCulloch in part because the Marshall Court evinced too great a willingness to sustain federal power. ${ }^{53}$ At the very least, therefore, one cannot deduce from Barbour's attack in Cohens on the judicial power to declare state laws unconstitutional that he also opposed the judicial power to declare federal laws unconstitutional. Opposition to the former may have entailed support for the latter.

The Jacksonian practice of appointing known proponents of judicial review to the federal bench suggests that judicial review survived the mid-nineteenth century because politicians wanted judicial review to survive, and not because the justices managed to separate law from politics. No shortage existed in 1835 of eligible candidates for the federal bench on record as opposing judicial review, particularly judicial review of state legislation. Nevertheless, Jackson and his successors in office when staffing the judiciary consistently passed over such opponents of broad judicial power as Judge John Bannister Gibson of Pennsylvania ${ }^{54}$ for politicians and lawyers who were either committed proponents of judicial power or at least visible conscientious objectors during the attacks on the judiciary made during the 1820s. Jacksonian efforts to buttress judicial power through legislation and judicial appointments may be partly explained by

\footnotetext{
${ }^{52}$ Warren, “Legislative and Judicial Attacks,” pp. 13-14, 16, 26, 30-32.

${ }^{53}$ FIND

${ }^{54}$ See Eakins v. Raub
} 
the general belief that an "independent and virtuous judiciary” would naturally interpret the constitution correctly. Jacksonians, however, had some fairly specific notions of what correct decisions an "independent and virtuous judiciary” would naturally reach.

\section{State Power}

Jacksonian Democrats do not appear as a group to be committed to state rights concerns that were independent of their commitment to certain limitations on federal power. Virtually every resolution in the Democratic party platforms adopted from 1840 until 1860 declares a constitutional or political restraint on federal power. None of these resolutions mention whether state exercise of that power was constitutional or desirable. Beginning in 1844, Democratic party platforms did assert that "congress has no power, under the Constitution, to interfere with or control the domestic institutions of the several States.” The main concern of that resolution, however, was to oppose any effort "to induce Congress to interfere with questions of slavery.” The platform's assertion that “such States are the sole and proper judges of everything pertaining to their own affairs" was immediately qualified by the clause "not prohibited by the Constitution." 55 No mention was made in any platform about the nature of those prohibitions.

\footnotetext{
${ }^{55}$ National Party Platforms, pp. 4,11,17,25. The Democratic platforms from 1840 and 1856 are almost identical. The 1860 platform of both the Douglas and Breckenridge factions saved space by simply “affirm[ing] . . . the resolutions adopted . . . by the Democratic Convention at Cincinnati, in the year 1856.” National Party Platforms, p. 30. See National Party Platforms, p.
} 
Every antebellum Democratic platform declared that federal powers must be "strictly construed.”56 None provided any guidelines for interpreting the constitutional limits Article I, Section 10 placed on state powers.

Jacksonian presidents seemed similarly unconcerned with most issues of state power that did not involve a corresponding limit on federal power. President Jackson and his successors do not appear to have taken public positions on the proper scope of the contracts clause, the scope of most of the other Article I, Section 10 prohibitions on state power or on the power of states to regulate such matters as interstate commerce, that even Jacksonians agreed the federal government could constitutionally regulate. When Jacksonian presidents took positions on pure state rights issues, they did not always favor state power. Jacksonians did enthusiastically support state efforts to establish jurisdiction of Native American tribes. ${ }^{57}$ On slavery, however, Jacksonians took positions that protected state rights in the south by limiting the power of northern states to pass personal liberty laws and protect abolitionist expression. President Jackson also attempted to make currencies policies that sharply limited the power of state banks to issue paper money, but this effort was abandoned.

No consensus on most pure state rights issues existed among Jacksonians at any level of government. Some Jacksonians in the national government were opposed to a national bank,

31.

${ }^{56}$ National Party Platforms, pp. 1, 3, 10,16, 24

${ }^{57}$ Daniel Feller, The Jacksonian Promise: America, 1815-1840 (Johns Hopkins University Press: Baltimore, 1995), pp. 179-80. 
others had more general objections to banks. "I did not join in putting down the Bank of the United States,” Thomas Hart Benton, a leading Jacksonian senator, declared, “to put up a wilderness of local banks. I did not join in putting down the paper currency of a national bank, to put up a national paper currency of a thousand local banks.”58 Jacksonians in state legislatures were at least as likely as Whigs to favor restricting state power. Jacksonians on state benches often interpreted state constitutional prohibitions as sharply curtailing the power of the state legislature. Jacksonian radicals occasionally criticized a Taney Court decision declaring some state law unconstitutional, but no case inspired a national groundswell suggestive of a broad Jacksonian consensus that the Supreme Court was wrongly limiting state powers. One reason for this may be a phenomenon dating back to the Marshall Court days. Judicial decisions declare a state law unconstitutional were typically supported by interests in neighboring states, regardless of whether that neighboring state tended to support Whigs or Democrats in national elections. State laws regulating interstate commerce, for example, tended to be supported by in-state interests and opposed by out-of-state interests, irrespective of partisan identification.

The relative low salience of and lack of general Jacksonian consensus on issues concerning the constitutionality of state laws helps explain why Jacksonian judicial nominees typically had exhibited no uniform tendency to support state interests in cases that did not involve limiting federal power. Justice Barbour, as noted above, had previously supported abandoning judicial review of state legislation. Wayne indicated some support for contract and commerce clause limitations on state power when in the Georgia legislature. Woodbury objected

\footnotetext{
${ }^{58}$ Swisher, Taney, p. 334 (Benton 1 Thirty Years’ View, p. 703).
} 
to some Marshall Court contracts clause cases but did declare some state laws unconstitutional when on the New Hampshire bench. Catron was a judicial activist as a state judge; Nelson as a state judge was more inclined to sustain state power. McKinley objected to Marshall Court decisions declaring state insolvency laws unconstitutional, but also spoke out against state laws that interfered with what he believed were federal prerogatives. ${ }^{59}$ Shortly before his nomination, Taney wrote a public memorandum which, while anticipating his conclusions in the $\underline{\text { Charles }}$

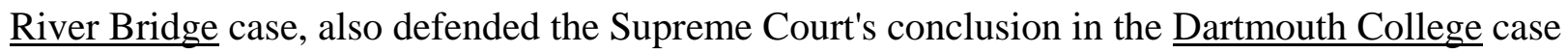
that corporate charters were contracts for Article I, Section 10 purposes. ${ }^{60}$ Taney as counsel for the state had argued in Brown v. Maryland that although the constitution forbade some state regulations of interstate commerce, states could tax certain goods that had already entered their jurisdiction. ${ }^{61}$ More generally, no Taney Court justice was publicly identified with or clearly committed to a position on the vast majority of constitutional issues debated by antebellum jurists that did not directly concern questions of federal power. The only pure issues of state power that sustained the attention of some Taney Court justices before their nomination were Indian removal, where state power was vigorously supported by Catron, McKinley, Wayne and

${ }^{59}$ Martin, "McKinley," pp. 21-22.

6015 Niles Weekly Register 151 (1833) FIND; Swisher, Taney Period, p. 79; Swisher, $\underline{\text { Roger }}$ Taney, pp. 365-67; 2 OPAG 512.

${ }^{61}$ FIND. See Swisher, Roger Taney, p. 114. 
Taney, ${ }^{62}$ and hard money, on which both Taney and Catron urged the limitations on state power necessary "to return to the constitutional currency of gold and silver."63

Jacksonian divisions on some and relative disinterest on other questions concerning the scope of constitutional limits on state power suggest that Taney Court decisions declaring state laws unconstitutional do not demonstrate a strong separation between law and politics. Jacksonian politics hardly dictated Taney Court decisionmaking in cases raising constitutional limitations on state power. The precise holding in such cases as Knoop and Cooley v. Board of $\underline{\text { Wardens }}^{64}$ cannot be deduced from particular Jacksonian understandings of the contracts clause or of the power of states to regulate certain manifestations of interstate commerce. No distinctive Jacksonian position on the contracts clause or federal exclusivity existed. The better understanding of Jacksonian politics explains why Jacksonian politics cannot explain the decisions in those cases. The low salience of most pure state rights questions in Jacksonian politics ensured that questions concerning constitutional prohibitions on the states played little role in the selection of those persons who staffed the Taney Court. Because Jacksonians differed on these questions, sucessiveful presidential efforts to secure orthodox Jacksonians for the

62 See State v. Foreman, FIND; Gass, "Catron," 55-58; Martin, "McKinley," p. 17; Swisher, Taney Period, pp. 53-54, 60-61.

63 Swisher, Taney Period, p. 110 (quoting Taney to Andrew Jackson, October 27, 1836), 113; Swisher, Roger Taney, pp. 339-40.

6453 U.S. 299 (1851). 
federal bench would not, by themselves guarantee that the justices selected would share a common understanding of constitutional limits on state power. Given the general Jacksonian commitment to limited federal power, few orthodox Jacksonians were likely to endorse all the limitations Justice Story would have placed on state governments. Most Jacksonians, the Jacksonians appointed to the Supreme Court in particular, thought the Marshall Court too inclined to limit state power. Still, the judicial revolution of 1837 exhausted whatever consensus may have existed within Jacksonianism on the proper interpretation of the contracts clause, the commerce clause and other constitutional limits on state power. On those constitutional issues that arose after 1837, the judicial selection process was likely to yield justices who had previously articulated different views on no views at all. Explanations of Taney Court decisionmaking on these matters, therefore, must focus on the attitudes and jurisprudence of individual Taney Court justices rather than the politics of their Jacksonian sponsors.

\section{Federal Power}

Jacksonian Democrats were relatively united in their effort to limit certain powers of the federal government. Many Jacksonians were nationalistic on issues concerning national expansion, but on matters concerning federal regulation of the economy, antebellum Democrats almost always advanced narrower conceptions of federal power than their Whig rivals. Democratic party platforms from 1840 to 1860 contained the identical declaration that "the federal government is of limited powers, derived solely from the constitution, and the grants of power shown therein, ought to be strictly construed by all the departments and agents of 
government, and that it is inexpedient and dangerous to exercise doubtful constitutional powers.” That assertion was immediately followed by nearly identical provisos declaring unconstitutional a national bank, any federal sponsored internal improvements, and various schemes to distribute to the states the proceeds from the sale of public lands. The protective tariff, while not expressly declared unconstitutional, was claimed to be inconsistent with “justice and sound policy.”65 Jacksonians in 1852 added a proviso stating that "the democratic party will faithfully abide by and uphold the principles laid down in the Kentucky and Virginia resolutions of 1798, and in the report of Mr. Madison to the Virginia legislature in 1799.",66

These platform declarations accurately reflect Jacksonian policymaking at the national level. Jacksonian executives in their public messages consistently articulated these and other limitations on federal power in their public messages. FIND. Consistent with these sentiments, Presidents Jackson, van Buren, Polk, Pierce and Buchanan almost never advocated policies that seemed unconstitutional according to Jacksonian constitutional understandings. Only on tariff issues did Democrats in the White House express some ambivalence, supporting reductions but

${ }^{65}$ National Party Platforms (Volume I) (edited by Donald Bruce Johnson) (University of Illinois Press: Urbana, 1978), pp. 1, 3-4, 10-12, 16-18, 24-27. The Democratic platform in 1860 simply referred readers to the Democratic platform in 1856, on the ground that "Democratic principles are unchangeable in their nature, when applied to the same subject matter.” National Party Platforms, p. 30 .

66 National Party Platforms, p. 17. This proviso was also included in the 1856 platform. National Party Platforms, p. 25. 
refusing to abandon the power to impose protective duties. ${ }^{67}$ With rare exceptions, Jacksonian presidents consistently vetoed measures that violated Jacksonian constitutional principles. Jacksonians were, like other American political coalitions, not completely unified on any political policy. Commitment to particular coalition goals varied by section, with some Jacksonians advancing even more extreme limits on federal power and others advocating policies that seemed unconstitutional by the standards laid down in the party platforms. ${ }^{68}$ Still, such Jacksonian congressional leaders as Thomas Hart Benton and Silas Wright were typically found opposing elements of the American plan. Rarely if ever did proposals for national banking laws, local internal improvements, distribution or protective tariffs enjoy substantial Democratic support in Congress. Democrats as a group were praised during the 1850s were "fearlessly resist[ing] at all hazards a scheme of internal improvements which would ultimately abstract hundreds of million from the treasury, and consolidate the federal government as the moneyed head of the nation." 69

Jacksonian politicians made self-conscious efforts to secure a federal judiciary committed to this narrow conception of federal power. Their crucial ideological qualification for nomination to the Supreme Court was opposition to any latitudinous construction of federal

${ }^{67}$ Feller, Democratic Promise, p. 164.

${ }^{68}$ See Daniel Feller, The Public Lands in Jacksonian Politics (University of Wisconsin Press: Madison, Wisconsin, 1984), pp. 141-42.

${ }^{69}$ See Swisher, Taney Period, p. 402. 
power. Jacksonian executives diligently searched to find jurists committed to this goal;

Jacksonians in the Senate killed nominations of persons who might support a national bank and similar exercises of federal power. ${ }^{70}$ Much evidence suggests that President Jackson and his successors could not have not a better job packing the Supreme Court with jurists predisposed to construe federal power narrowly. From the time Taney took over the reins of the Court until his death, a clear judicial majority existed on public record as strongly opposed to the national bank and federal sponsored internal improvements. Moreover, the Jacksonians on the Court were, almost without exception, militant Jacksonian politicians who did not significantly limit their partisan activities after joining the bench. No evidence exists that Jacksonians made a strong separation between law and politics or that Jacksonian jurists thought their judicial positions required anything more than a certain discreteness when engaging in partisan behavior. Given the strong support from the presidency the justices could expect from 1836 until1848 and from 1852 until 1860, virtually every model of judicial decisionmaking that does not recognize a strong separation between law and politics would predict that the Taney Court should have been the most activist bench in American history, at least on questions of national power.

\section{B. Jacksonian Justices as Jacksonian Politicians}

Jacksonian executives sought to break the perceived Federalist stranglehold on the

${ }^{70}$ Warren, 2 The Supreme Court, p. 243. 
judiciary ${ }^{71}$ by appointing to the Supreme Court veterans of the Bank War with close personal and partisan connections to other influential Jacksonian leaders. Many Jacksonian judicial nominees first attracted public notice during the political struggles over the appropriate scope of federal power contested during the 1820s, 1830s and 1840s. Roger Taney, Levi Woodbury, James Wayne, Philip Pendleton Barbour, John McKinley, Nathan Clifford, and John Catron played prominent roles in Jacksonian fights against the national bank and American system. Taney and Woodbury were trusted members of Jackson's cabinet (McLean was appointed in part because on patronage matters he was not a trusted member of Jackson's cabinet; ${ }^{72}$ Daniel turned down an invitation to join the cabinet ${ }^{73}$ ), Woodbury was in Van Buren's cabinet (Daniel again turned down a position ${ }^{74}$ ), and Clifford was attorney general in the Polk administration. Woodbury had

\footnotetext{
${ }^{71}$ Actually, the Marshall Court is more accurately characterized as a national Republican or proto-Whig Court. Jacksonian rhetoric consistently tarred both factions with the "Federalist" label, ignoring the substantial contributions of such former Federalists as Roger Taney to the Jacksonian cause. For a lengthy discussion of these points, see Mark A. Graber, "Federalist or Friends of Adams: The Marshall Court and Party Politics,” 12 Studies in American Political
} Development 229 (1998).

${ }^{72}$ Abraham, Justices and Presidents, p. 97; Swisher, Roger Taney, pp. 132-33.

${ }^{73}$ Swisher, Roger Taney, p. 245.

${ }^{74}$ Daniel remained “one of [Van Buren’s] most effective advisors.” Abraham, $\underline{\text { Justices and }}$ Presidents, p. 105 
received serious consideration as possible Jacksonian presidential candidate; Barbour was almost the Jacksonian nominee for the vice presidency in $1832 .^{75}$ Woodbury, Wayne, Barbour, McKinley, and Clifford were Jacksonian leaders in Congress; Nelson was a Jacksonian candidate for the Senate. Baldwin, Taney, Catron, McKinley, and Daniel played major roles organizing Jacksonian forces in Pennsylvania, Maryland, Tennessee, Alabama, and Virginia respectively. ${ }^{76}$ Indeed, every Democrat seriously considered for a Supreme Court seat during the thirty years before the Civil War, with the exception of Grier and, possibly, Nelson, was a seasoned political veteran. James Buchanan, who rejected an invitation from Polk (and from Tyler), ${ }^{77}$ had previously been a Jacksonian leader in the House of Representatives, a member of President Polk’s cabinet, and a leading candidate for the presidency, a post he would later obtain. Next to Jackson and Martin Van Buren (whom Tyler strongly considered appointing to the Supreme Court), ${ }^{78}$ Buchanan was probably the most influential Jacksonian politician in antebellum

${ }^{75}$ See Swisher, Roger Taney, p. 433, 443.

${ }^{76}$ See Abraham, Justices and Presidents, p. 98 (“[l]ong an aggressive and enthusiastic supporter, Baldwin had been instrumental in bringing Pennsylvania into the Jacksonian fold in the election of 1828"), 99 (Taney); 102-03 (Catron), 104 (“McKinley had been one of Van Buren’s key managers during the presidential campaign of 1836 and was personally responsible for capturing Alabama’s electoral votes”), 104-05 (Daniel); Swisher, Roger Taney, pp. 125-29, 296-98.

77 Abraham, Justices and Presidents, pp. 106, 108-09.

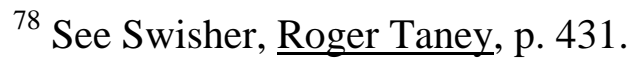


America. William Smith, who rejected two invitations from Jackson, served in both the Alabama and South Carolina state legislatures, represented South Carolina for ten years in the Senate of the United States, and was responsible for the first state resolution declaring unconstitutional both protective tariffs and federal sponsored internal improvements. ${ }^{79}$ Silas Wright, who rejected a Tyler invitation, was generally considered the second most influential Jacksonian in New York, next to van Buren. Wright served terms in the New York legislature, in the House of Representatives, in the Senate, and as Governor of New York. ${ }^{80}$ Black, whose nomination by Buchanan was rejected by the Senate, had been the Attorney General in the Buchanan administration. before being asked to join the Supreme Court. Had Jackson been able to fill a third vacancy on the Supreme Court before the Bank War, he probably would have fulfilled his promise to give that appointment to Louis McLane, the Secretary of the Treasury. ${ }^{81}$ Had McLean been considered a politically more reliable Postmaster General, his Supreme Court seat would have gone to William Barry, a Kentucky politician whose, instead, became the Postmaster General. Black was the only one of these Democrats considered for the Supreme

${ }^{79}$ See J.G. DeR. Hamilton, “Smith, William,” Dictionary of American Biography (Volume IX) (edited by Dumas Malone) (Charles Scribner’s Sons: New York, 1936), pp. 359-61; Abraham, Justices and Presidents, p. 98.

${ }^{80}$ Marian Silveus, “Wright, Silas,” Dictionary of American Biography (Volume X) (edited by Dumas Malone) (Charles Scribner’s Sons: New York, 1936), pp. 365-67.

${ }^{81}$ Swisher, Roger Taney, p. 161. 
Court who had any substantial experience as a judge and lawyer. Significantly, Buchanan, Wright and Smith were all on public record as regarding the national bank and other Whig measures unconstitutional. Black almost certainly held these views, and Barry supported Jackson during the Bank War. McLane did not obtain his desired appointment to the Supreme Court in part because he did not support Jackson during the Bank War

The Jacksonian tendency to prefer seasoned veterans for judicial vacancies provides a common benefit to Jacksonians and future scholars: known opinions on the vital questions of the day. Jacksonian executives could have a high degree of confidence that their judicial nominees were committed Jacksonians, given their past activities and speeches on behalf of the Democratic party and that party's commitment to limited federal power over the economy. These public activities also left a paper trail that enables scholars at the dawn of the twenty-first century to determine the attitudes of most Jacksonian jurists on those issues that divided Whigs from Democrats. Hence, an attitudinal model of Taney Court decisionmaking can be constructed that does not rely on the circular practice of using judicial votes to establish judicial attitudes or, almost as bad, uses newspaper predictions of judicial votes to establish judicial attitudes. This biographical approach demonstrates is that both nineteenth century Jacksonians and contemporary scholars should have expected with a high degree of certainty that Taney Court would be fierce opponents of the national bank and related American System measures.

\section{B. Taney Court Attitudes on Jacksonian Policies}

The judicial majority on the Taney Court was politically predisposed to overrule or at 
least significantly narrow McCulloch v. Maryland. ${ }^{82}$ Five Taney Court justices, Chief Justice Roger Taney, Justices Philip Pendleton Barbour, Peter Daniel, Nathan Clifford and Levi Woodbury had, while in political office, declared that the national bank was unconstitutional. The other orthodox Jacksonian members of the Taney Court were either leading opponents of the national back (Justices James Wayne, James Catron, John McKinley, and possibly Samuel Nelson) or at the very least identified with political factions or political leaders that regarded the bank as unconstitutional (Robert Grier and John Campbell). Only five justices who sat during the Taney era, Justices Joseph Story, Smith Thompson, Henry Baldwin, John McLean, and Benjamin Curtis could be counted on as relative sure votes for sustaining the national bank, and at no time did these five justices sit together. Taney Court justices who had fought the bank on constitutional grounds in the national legislature or national executive might nevertheless have thought the court lacked the power to strike down a law authorizing the national bank. Still, the most probable swing votes on that question from 1845 to 1860, Justices Wayne and Catron, were militant opponents of the bank who retained strong Jacksonian political connections. Two other swing justices, Justices Grier and Nelson, exhibited no such judicial modesty after the Civil War when declaring that the government had no power to make paper money legal tender for private debts. $^{83}$

\section{The Jacksonians}

${ }^{82}$ FIND

83 FIND 


\section{a. Hardliners}

Chief Justice Roger Taney, Justice Peter Daniel, Justice Philip Pendleton Barbour, Justice Levi Woodbury, and Justice Nathan Clifford were the Jacksonian jurists most likely to declare Whig measures unconstitutional. All before joining the Supreme Court had publicly declared that the national bank and some other elements of the American System were unconstitutional. No evidence exists that any of these justices became more Whiggish during their years on the bench. Barbour was the only justice in this group who had previously expressed qualms about judicial power, and his attack on the judicial power to declare state laws unconstitutional may have entailed the judicial power to declare federal laws unconstitutional.

Justice Daniel was an almost certain vote to strike down Whig policies. Daniel, “a major Jackson-Van Buren lieutenant in Virginia” before joining the federal bench, ${ }^{84}$ opposed virtually every proposal in the American System and did so on constitutional grounds. With reference to an unknown political actor, Daniel in 1840 declared, “(h)e has professed a belief in the constitutionality of a national bank, and that is an objection which with me would overrule any and every recommendation which could be urged for him or for any other person." ${ }^{85}$ Daniel in

84 John P. Frank, Justice Daniel Dissenting: A Biography of Peter V. Daniel, 1784-1860 (Harvard University Press: Cambridge, Massachusetts, 1964), p. 77.

${ }^{85}$ Frank, Daniel, p. 113 (quoting Daniel to William Brent, February 29, 1840). See Frank, Daniel, p. 111; Swisher, Taney Period, p. 67; Swisher, Roger Taney, pp. 428-29. 
1843 informed Martin Van Buren that “(s)ince a protective tariff necessarily aided selective industries, it was a discrimination and hence unconstitutional.”86 ${ }^{86}$ Then President Polk vetoed on constitutional grounds an internal improvement bill, he received a note on congratulations from Daniel urging him to stand firm against any future congressional legislation of that ilk. ${ }^{87}$ Justice Barbour seems almost as certain as Justice Daniel to strike down American plan measures. Barbour was “as representative a Virginia strict constructionist as can be found."88 In Congress much of the time between 1816 and 1831, he was a leading, if not the leading opponent of broad exercises of national authority. ${ }^{89}$ Barbour insisted that "the framers of the Constitution meant to guard as carefully against the latitudinous construction which might be given to indefinite powers," and maintained that all federal measures had to have an "immediate, direct, and obvious relation to the power granted." ${ }^{90}$ On the floor of the Congress, he declared internal

${ }^{86}$ Frank, Daniel, pp. 164-65 (quoting Daniel to Martin Van Buren, July 6, 1843).

${ }^{87}$ Swisher, Taney Period, p. 400 (quoting Daniel to Polk, August 5, 1846). See Frank, Daniel, p. 315 n.3. See also, Frank, Daniel, p. 213 (“Daniel’s detestation of internal improvements financed by the federal government was as great as his hatred of banks, and he could easily claim that they were unconstitutional”).

${ }^{88}$ Gatell, “Barbour,” p. 717.

${ }^{89}$ Feller, Public Lands, p. 50; Swisher, Taney Period, p. 56.

${ }^{90}$ Annals of Congress, $15^{\text {th }}$ Cong., $1^{\text {st }}$ Sess., p. $627 ; 14^{\text {th }}$ Cong., $2^{\text {nd }}$ Sess., p. 694. See Annals of 
improvements, protective tariffs, a national bankruptcy law and a national bank unconstitutional. When defending Jackson's veto of the Maysville road bill, Barbour indicated that his only quarrel with administration policy was that Jackson too broadly defined national power when claiming that the federal government could constitutionally build roads in certainly narrowly defined circumstances. "We are not authorized to construct post roads or military roads,” he elsewhere declared, “or dig canals, either by any power expressly granted or properly to be inferred.”91 The Marshall Court, he informed fellow representatives, had "enlarged the sphere of its actions ... to an indefinite extent beyond what was in contemplation of those who formed it. $^{\text {992 }}$

Justices Levi Woodbury and Nathan Clifford were also highly likely to declare American plan measures unconstitutional. Woodbury was "a strict constructionist of the Constitution” who

Congress, $15^{\text {th }}$ Cong., $1^{\text {st }}$ Sess., 1156 ("natural, direct, and obvious relation).

${ }^{91}$ Annals of Congress, $21^{\text {st }}$ Cong., $1^{\text {st }}$ Sess., pp. 1143-44; Annals of Congress, $15^{\text {th }}$ Cong., $1^{\text {st }}$ Sess., p. 1152. See Annals of Congress, 14 Cong., $2^{\text {nd }}$ Sess., pp. 893-99; $17^{\text {th }}$ Cong., $1^{\text {st }}$ Sess., pp. 604-05, 1060-71; $18^{\text {th }}$ Cong., $1^{\text {st }}$ Sess, pp. 1005-13, 1151-60, 1918; $16^{\text {th }}$ Cong., $1^{\text {st }}$ Sess., p. 1221; $20^{\text {th }}$ Cong., $1^{\text {st }}$ Sess., 1513, 1645. See Swisher, Roger Taney, p. 113 (quoting Barbour to Martin Van Buren, December 16, 1841); Gatell, “Barbour,” pp. 719, 724-25; P.P. Cynn, “Philip Pendleton Barbour,” 4 Randolph-Macon Historical Papers 67, 70, 72,75 (1913); See Roper, Thompson, p. 107; Swisher, Roger Taney, p. 172 (noting that Barbour in Congress “initiated one of the early skirmishes” in the Bank War).

92 Annals of Congress, $20^{\text {th }}$ Cong., $1^{\text {st }}$ Sess., p. 1645. 
“deplored” McCulloch v. Maryland. ${ }^{93}$ "A national banking corporation," he frequently declared, "is at all times and in all forms, unconstitutional."94 While "an integral part of Jackson’s administration, ${ }^{, 95}$ he urged the president to veto the bill rechartering the national bank and helped write the veto message declaring that institution unconstitutional. ${ }^{96}$ Woodbury was also a prominent Jacksonian leader in both houses of Congress, where he consistently condemned both the national bank and internal improvements on constitutional grounds. ${ }^{97}$

Clifford was a slightly less prominent clone of Woodbury, who he regarded as one of

${ }^{93}$ Philip D. Wheaton, Levi Woodbury: Jacksonian Financier (PhD. Thesis, University of Maryland, 1955), p. 14. See Annals of Congress, $21^{\text {st }}$ Cong., $1^{\text {st }}$ Sess., pp. 185-86.

${ }^{94}$ Annals of Congress, $27^{\text {th }}$ Cong., $1^{\text {st }}$ Sess., Appendix, p. 180 . See $27^{\text {th }}$ Cong., $1^{\text {st }}$ Sess., Appendix, p. 41 (“the State Rights man or Democrat of 1798, who can swallow this new fiscal Bank as constitutional, could swallow both Jonah and the whale as easy as the whale did Jonah alone").

${ }^{95}$ Wheaton, Woodbury, p. 80.

${ }^{96}$ Wheaton, Woodbury, pp. 42-45; Swisher, Roger Taney, p. 231; Swisher, Taney Period, p. 101.

${ }^{97}$ See Annals of Congress, $27^{\text {th }}$ Cong., $1^{\text {st }}$ Sess., Appendix, pp. 18, 41-42, 179-80; $27^{\text {th }}$ Cong., $1^{\text {st }}$ Sess., pp. 23, 108, 177, 192, 260, 380; $21^{\text {st }}$ Cong., $1^{\text {st }}$ Sess., pp. 179-86. Woodbury did believe that the federal government had the power to build lighthouses, a claim also made by Jacksonian executives. See $21^{\text {st }}$ Cong., $1^{\text {st }}$ Sess., pp. 432-33. 
“the great men of our county."98 Both were New England Jacksonians, had extensive political careers before joining the bench, and were commited throughout their political life to limiting national power. ${ }^{99}$ Clifford first came to national attention as the author of a state resolution against reincorporating the national bank. ${ }^{100}$ His legislative speeches consistently endorsed that position. He was “opposed to a National Bank,” Clifford informed Congress, "believing it to be both unconstitutional and inexpedient.”101 Clifford also gave speeches in Congress indicating that internal improvements, protective tariffs and efforts to give to the states proceeds from the sale of public lands were similarly unconstitutional. ${ }^{102}$ While a member of Polk's cabinet, he helped write presidential veto messages declaring internal improvements unconstitutional. ${ }^{103}$

98 Philip Greely Clifford, Nathan Clifford: Democrat (G.P. Putnam’s Sons: New York, 1922), pp. 49-50.

${ }^{99}$ Clifford, Clifford, pp. 13 (“ardent Jackson supporter”), 42-44, 103; Walter Chandler, “Nathan Clifford: A Triumph of Untiring Effort,” 11 American Bar Association Journal 57, 57 (1925).

${ }^{100}$ Annals of Congress, $23^{\text {rd }}$ Cong., $1^{\text {st }}$ Sess., p. 148.

${ }^{101}$ Annals of Congress, $26^{\text {th }}$ Cong., $1^{\text {st }}$ Sess., Appendix, p. 475 . See $26^{\text {th }}$ Cong., $1^{\text {st }}$ Sess., p. 357; $26^{\text {th }}$ Cong., $1^{\text {st }}$ Sess., p. 471.

102 See Annals of Congress, $26^{\text {th }}$ Cong., $1^{\text {st }}$ Sess, Appendix, pp. 475-76; $27^{\text {th }}$ Cong., $1^{\text {st }}$ Sess., pp. 127-30; $27^{\text {th }}$ Cong., $1^{\text {st }}$ Sess., pp. 92, 96. See Clifford, Clifford, pp. 109, 115-17, 126-29.

${ }^{103}$ See Paul H. Bergeron, The Presidency of James K. Polk (University Press of Kansas: 
Taney may have been the most orthodox Jacksonian of all. As Daniel Feller notes, he “stood closer to the ideological heart of Jacksonianism than anyone save Jackson himself.”104 Taney first came to national prominence as the person who helped write Jackson's veto of the bank bill, a veto that insisted the bank was neither constitutionally necessary nor constitutionally proper. ${ }^{105}$ Significantly, Taney was a leader in the Bank War, and not a mere administration mouthpiece. He was the first member of the cabinet to insist that the bank was unconstitutional, wrote a memo to Jackson urging him to veto the bill on numerous constitutional grounds, and was the only member of the cabinet who consistently supported Jackson's effort to remove federal deposits from the national bank. ${ }^{106}$ “The overthrow of The Monster,” he later wrote, “was the greatest of all great public services of Genl. Jackson.”"107 Taney also opposed on constitutional grounds other Whig proposals, in particular bills that would distribute surplus federal revenue to the states. "[T]he revenue which the government is authorized to raise," he

Lawrence, Kansas, 1987), p. 197.

${ }^{104}$ Feller, Democratic Promise, p. 176.

105 See Warren, 2 Supreme Court, pp. 100-05; Swisher, Taney Period, p. 20; Swisher, Roger Taney, pp. 190-92, 194-95. Not surprisingly, Taney also approved when Tyler vetoed a national bank bill. Swisher, Taney, p. 345 (quoting Taney to Jackson, September 30, 1841).

${ }^{106}$ For Taney’s participation in the Bank War, see Swisher, Roger Taney, 176-77, 180-81, 18993, 218-19, 228, 230-32, 258, 333-34

107 Swisher, Taney Period, p. 127 (quoting Taney to Ellis Lewis, October 25, 1845). 
informed President Jackson, “was intended to be used for national purposes only, and whenever it shall exceed what may be useful and constitutionally employed in the exercise of its legitimate duties it is bound to reduce it.”108 Such assertions suggest Taney believed that both distribution and protective tariffs were unconstitutional. ${ }^{109}$

The five Jacksonian hardliners never formed a judicial majority. The terms of Justices Barbour, Woodbury, and Clifford did not overlap, and the first two were on the Court for a mere six years. Only from 1845 to 1851, and from 1859 to 1860 did as many as three justices who can clearly be identified on record as regarding most Whig proposals unconstitutional sit on the bench. If Whig measures were to be condemned, the Taney Court hardliners would have to gain the votes of other Jacksonian appointees, appointees whose position on the constitutionality of American plan proposals was less clear.

\section{b. Swings?}

108 Swisher, Roger Taney, pp. 329-30.

109 Taney, however, had previously suggested that protective tariffs were constitutional. See Swisher, Roger Taney, p. 155. Moreover, Taney endorsed Jackson’s decision to sign a modified version of the distribution bill that mere deposited federal surpluses with state governments. He emphasized, however, that "if [Jacksonians in the federal government did] not bring it back from the states, they will be compelled to sanction a principle, which is directly at war with that construction of the federal constitutional for which they have been so long contending.” See Swisher, Roger Taney, pp. 330-31 (quoting 5 Correspondence of Jackson, 409-11). 
Justices John McKinley, John Catron, James Wayne, Samuel Nelson, Robert Grier, and John Campbell were the probable swing votes during the Taney years on issues concerning constitutional status of various American System measures. Had these justices voted as a bloc, a high probability exists that the result they favored would have commanded a judicial majority on the Taney Court. It is hard to image circumstances where these justices voted to sustain a Whig program, but the Jacksonian hardliners gained the votes from at least two of the Whigs on the Court necessary to declare the measure unconstitutional. Similarly, if these justices voted as a bloc to strike down a measure, they were highly likely to pick up the one or two votes necessary from a Jacksonian hardliner (Daniel in particular) to form the majority necessary to declare the measure unconstitutional.

Significantly, with the exception of Justice McKinley, the other five justices are considered swing votes primarily because of a relative lack of easily accessible information on their constitutional attitudes towards the national bank, internal improvements, and similar measures. All were life-long Democrats. With the exception of Nelson, who was appointed by the psuedo-Whig, Tyler, all were appointed by Democratic presidents who repeatedly vetoed Whig measures on constitutional grounds and insisted that they only appointed to the Supreme Court jurists who would narrowly construe federal powers. Still, in part because with the exception of Wayne and McKinley, the Jacksonian swings did not serve in Congress, the existing evidence does not permit the same degree of confidence that Justices Grier, Nelson, Campbell, Wayne, Catron had the same constitutional objections to the American System as did Chief Justice Taney, and Justices Daniel, Barbour, Woodbury, and Clifford. 
Virtually no primary or secondary evidence exists on the political attitudes of Robert Grier on those issues that divided Jacksonians from Whigs. Grier was a "life long Democrat,” who owed his appointments to the state and federal bench to his partisan affiliations. ${ }^{110}$ The Governor of Pennsylvania, when recommending Grier to President Polk, claimed that Grier was "a sincere and steadfast advocate" of "[t]he rights guaranteed by the constitution to the states-the republican doctrine of state rights-opposition to a national bank-all the cardinal principles of the democratic party.”111 Alas, no easily accessible public statement made by Grier has survived that specifically expresses his attitudes on the expedience or constitutionality of any element of the American plan.

Evidence on Justice Samuel Nelson's political attitudes is almost as sparse, other than that he was more involved than Grier in both local and national Democratic party politics. Nelson was closely associated with the Van Buren wing of New York Democrats, was their nominee for the Senate in 1844, and was apparently considered for the Democratic presidential

${ }^{110}$ Francis R. Jones, “Robert Cooper Grier,” 16 The Green Bag 221, 223 (1904). See Frank Otto Gatell, “Robert C. Grier,” The Justices of the United States Supreme Court 1789-1978: Their Lives and Major Opinions (Volume II) (edited by Leon Friedman and Fred L. Israel) (Chelsea House Publishers: New York, 1980); Abraham, Justices and Presidents, p. 109. Virtually nothing has been written on Grier, and few of his personal papers remain.

${ }^{111}$ Swisher, Taney Period, pp. 231-32. Swisher previously claimed that Grier “opposed the Bank of the United States on grounds of constitutionality and of expediency,” but did not cite primary evidence for this assertion. Swisher, Roger Taney, p. 444. 
nomination in $1860 .^{112}$ Edward Countryman asserts that Nelson while on the bench maintained “a deep interest in public affairs and entertained decided opinions upon all questions of National policy," but does not reveal what those opinions were. ${ }^{113}$ As was the case with Grier, one might suspect he shared Jacksonian hostility to national banks and internal improvements. This inference is somewhat stronger for Nelson, given the near impossibility of anyone being the New York Democratic nominee for the Senate in 1844 who was not known to regard most Whig proposals as unconstitutional.

More information exists on Justice Campbell, but existing evidence presents a somewhat conflicting position on his attitude towards the national bank, internal improvements and other Whig measures. During the 1830s, Campbell publicly identified with the Jacksonian coalition in Alabama that supported Jackson’s Maysville veto and his veto of the bill rechartering the

112 See Edwin Countryman, “Samuel Nelson,” 19 The Green Bag 329 (1907); Richard H. Leach, “The Rediscovery of Samuel Nelson,” 34 New York History 64, 65 (1953) (“there is reason to believe he was not without political influence in the Democratic Party as well”); Frank Otto Gatell, “Samuel Nelson,” 2 The Justices of the United States Supreme Court, pp. 818, 825 (noting that Nelson was "seriously mentioned as a possible Democratic candidate for President" in 1860).

${ }^{113}$ Countryman, “Nelson,” p. 333. Nelson on the New York bench was clearly supportive of state chartered banks and internal improvements, but this was quite consistent with orthodox Jacksonian doctrine. See Gatell, “Nelson,” pp. 819-22. 
national bank. ${ }^{114}$ On the other hand, Campbell's most recent biographer maintains that during this time period, the future justice privately maintained an "all-but-Whig ideology."115 While publicly supporting the Jacksonian candidate for Senate in 1836, Campbell privately declared he “infinitely preferred the alternative,” a candidate on record as supporting "the constitutionality of tariff laws, of internal improvements, and [of] the incorporation of a national bank.” Campbell quickly added, however, that his preferred candidate, Judge Hopkins “disclaims all idea of aiding in any \& abhors the policy of each.” Moreover, his criticisms of the rival candidate, future Justice John McKinley, were entirely on personal grounds. ${ }^{116}$ Thus, a fair inference exists that

${ }^{114}$ Christine Jordan, “Last of the Jacksonians,” Supreme Court Historical Yearbook, 1980 (Supreme Court Historical Society: Washington, D.C., 1980), p. 80. See Robert Saunders, Jr., John Archibald Campbell, Southern Moderate, 1811-1889 (University of Alabama Press:

Tuscaloosa, 1997), p. 30. As was the case with most Jacksonian judicial appointees, Campbell was also publicly opposed to nullification. See Jordan, “Last of the Jacksonians,” p. 80; Saunders, Campbell, p. 29-30.

115 Saunders, Campbell, pp. 55-56. See Saunders, Campbell, pp. 39, 69.

${ }^{116}$ Campbell to Henry Goldwaithe, November 29, 1836, Campbell Family Papers, \#135, Fol. 3, Southern Historical Collection, Library of the University of North Carolina at Chapel Hill See Saunders, Campbell, p. 31. When Campbell in 1836 asserting that he was "acting now with a party with form all of whose tenets I feel I should be opposed,” he was expressing opposition to nullification, not Jacksonianism. The letter indicates that between "nullifiers, consolidationists \& 
Campbell supported Hopkins despite rather than because of that candidate's constitutional positions. More significantly, Campbell by 1850 had "reassessed what he perceived as the fundamental meaning of the constitution” and had developed an “increasingly inflexible states' rights philosophy."117 The New York Tribune when Campbell was nominated declared him "about the ablest man connection with the ultra State-Rights organization, ... filled with all the dogmas and mad metaphysics of Mr. Calhoun."118 Still, Campbell’s precise opinions on federal power in matters unrelating to slavery cannot be identified with any degree of certainty at the time of his nomination to the federal bench. Campbell's nomination was strongly supported by state's rights advocates, but whether that support transcended slavery issues is unclear. Campbell in 1860 privately noted that southerners objected to the national bank, but did not indicate whether he shared that aversion. ${ }^{119}$

Justice Wayne’s political opinions are far easier to discern. As a Jacksonian representative from Georgia during the 1820s, Wayne led the fight against Whig efforts to

federalists," Campbell identified as a federalist, but what that meant in terms of American plan policies is unclear. Campbell to Henry Goldwaithe, November 29, 1836.

117 Saunders. Campbell, pp. 83, 115. See Saunders, Campbell, pp. X, 30, 68, 87, 93. After the war, Campbell continued to insist that the power of the federal government was strictly limited. See Saunders, Cambell, pp. 225-27.

${ }^{118}$ Warren, 2 Supreme Court, p. 246.

119 See Saunders, Campbell, pp. 105, 138 (quoting FIND). 
recharter the national bank. One influential Jacksonian listed Wayne as “among the ten zealous, able, determined” members of the House who support Jackson administration banking policy. ${ }^{120}$ Wayne also specifically praised Jackson's veto of the Maysville Road Bill and condemned the protective tariff as unconstitutional. ${ }^{121}$ His biographer concludes that "Wayne had no trouble in subscribing to his party's platform, which was distinctly Jacksonian in tone. It opposed the Bank of the United States, the principle of the protective tariff, and Internal Improvements by the general government.”122 Wayne is classified as a Jacksonian swing only because, although he indicated that he regarded protective tariffs and federal sponsored internal improvements unconstitutional, no record exists of Wayne explicitly declaring the national bank unconstitutional (or constitutional). Still, Wayne interpreted federal powers quite narrowly. His speeches called for "a limitation of the action of the Government to the text of the constitution" and rejected "the employment of all means, which are not essential to the execution of a

${ }^{120}$ Alexander A. Lawrence, James Moore Wayne: Southern Unionist (University of North Carolina Press: Chapel Hill, 1943), p. 72 (quoting Thomas Hart Benton). See Lawrence, Wayne, pp. 71-74; Annals of Congress, $23^{\text {rd }}$ Cong., $1^{\text {st }}$ Sess., p. $350 ; 22^{\text {nd }}$ Cong., $1^{\text {st }}$ Sess., p. 2132; $21^{\text {st }}$ Cong., $2^{\text {nd }}$ Sess., pp. 351, 353; Frank Otto Gatell, “James M. Wayne,” 1 The Justices of the United States Supreme Court, p. 604; Swisher, Taney Period, pp. 25-26, 54.

${ }^{121}$ Annals of Congress, $21^{\text {st }}$ Cong., $1^{\text {st }}$ Sess., pp. 1147-48; $21^{\text {st }}$ Cong., $2^{\text {nd }}$ Sess., p. 390 . See Lawrence, Wayne, pp. 40-41, 101-02; Annals of Congress, $23^{\text {rd }}$ Cong., $1^{\text {st }}$ Sess., p. 461.

${ }^{122}$ Lawrence, Wayne, p. 75. See Gatell, Wayne,” p. 604. 
substantially granted power.”123 Wayne in 1854 declared he gave national powers “a rational and limited interpretation” as opposed to those "whose tendency has been to give [the national government] legislative ability in cases where the power has not been delegated to the United States by the Constitution, or when power have been asserted by the Legislation of the United States, which were reserved to the States respectively or the people.”124

That Justice Wayne was at least a Jacksonian swing and probably a Jacksonian hardliner may seem mistaken in light of voting analyses which seem to confirm Justice Curtis’s initial impression that Wayne and McLean were the two "most high-toned Federalists on the bench.”125 Wayne did exhibit a strong nationalist strain on the bench, particularly on issues of federal jurisdiction and the exclusivity of the federal commerce power. ${ }^{126}$ These votes, however, hardly

${ }^{123}$ Annals of Congress, $21^{\text {st }}$ Cong., $1^{\text {st }}$ Sess., p. 701; James M. Wayne, “Address,” ThirtySeventh Annual Report of the American Colonization Society (C. Alexander, Printer: Washington, 1854), p. 40. See Lawrence, Wayne, p. 111.

${ }^{124}$ Wayne, “Address,” p. 41.

${ }^{125}$ Curtis, Curtis, p.168 (quoting Benjamin Robbins Curtis to Mr. Ticknor, February 29, 1852).

See Lawrence, Wayne, pp. 93-94; Jeffrey A. Segal and Harold J. Spaeth, The Supreme Court and

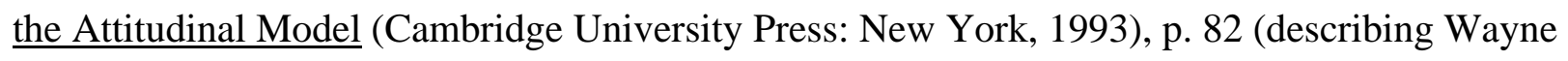
as “staunchly Hamiltonian”).

${ }^{126}$ FIND. See Lawrence, Wayne, p. viii (describing Wayne as “a Georgian who made love of the Federal Union the governing principle of his political and judicial career”). 
suggest Jacksonian apostasy. Jacksonians, as noted above, increasingly supported expanding the jurisdiction of federal courts and never reached a consensus on whether the federal commerce power was exclusive. Moreover, Wayne had exhibited the same mixture of localist and nationalist sentiments while in Congress. At the same time he was battling against the national bank and internal improvements, Wayne supported all military appropriations and was the only representative from Georgia who voted for the Jackson Force Bill, with its dramatic increase in federal habeas corpus jurisdiction. ${ }^{127}$ Significantly, Wayne’s commitment to exclusive federal power did not entail any commitment to broad federal power. He strongly supported Justice Story’s nationalistic assertion in Prigg v. Pennsylvania that only the federal government could pass laws concerning fugitive slaves, ${ }^{128}$ but was also the justice most responsible for placing the court on record in Dred Scott as holding that the federal government had no power to prohibit slavery in the territories. ${ }^{129}$ That Wayne considered the federal commerce power to be exclusive, therefore, does not provide sufficient clues to how broad he thought that power was.

${ }^{127}$ See Lawrence, Wayne, pp. 55, 63-65. See Gatell, “Wayne,” pp. 603-04. Wayne also strongly supported Jacksonian efforts to remove the Cherokees from Georgia. See Lawrence, Wayne, p. 62.

${ }^{128}$ FIND. See Lawrence, Wayne, p. 141.

${ }^{129}$ FIND. All commentators agree that Wayne was the moving force behind the judicial decision to issue a broad ruling in Dred Scott. See Lawrence, Wayne, pp. 147-49, 155; Curtis, Curtis, pp. 206-07, 234-36; Swisher, Roger Taney, pp. 497-98. 
Significantly, perhaps, his biographer thought that Wayne would have declared internal improvements unconstitutional had the issue arose. ${ }^{130}$ Justice Curtis may have associated Wayne and McLean, but Justice McLean during the early 1840s complained that Wayne, Catron, Daniel and Thomson had formed a judicial alliance against the proto-Whigs on the Court. ${ }^{131}$

Justice Catron was also a prominent Jacksonian political actor, a "longtime personal and political friend” of President Jackson, and a self-described “enem[y] of the U.S. Bank."”132 During the bank wars, Catron organized support for Jackson administration policy, and wrote several articles condemning that institution. ${ }^{133}$ Just before being appointed to the federal bench,

${ }^{130}$ Lawrence, Wayne, p. 102.

${ }^{131}$ See Frank, Daniel, p. 171 FIND letter

${ }^{132}$ Abraham, Justices and Presidents, p. 192; Walter Chandler, The Centenary of Associate Justice John Catron of the United States Supreme Court (S.C. Toof \& Co.: Memphis, Tennessee, 1937), p. 29-(quoting John Catron to Andrew Jackson, February 5, 1838). See Joshua Williams Caldwell, Sketches of the Bench and Bar of Tennessee (Ogden Brothers: Knoxville, 1898), p. 87 (“[f]or many years [Catron] had been one of Jackson’s most ardent admirers and most efficient supporters”); Frank Otto Gatell, “John Catron,” 1 The Justices of the Unied States Supreme Court, p. 738 (describing Catron as “one of the leading Jackson men”), 748-49.

${ }^{133}$ See Gatell, “Catron,” pp. 739-40. Chandler, Catron, p. 15; Roper, Thompson, p. 108; Sellers, Polk: Jacksonian, pp. 174-75 (the articles are in Nashville Republican 6/12, 26, 30, 7/3, 7/29), 321; Gass, “Catron,” pp. 54-55; Swisher, Taney Period, pp. 60, 113. 
Catron urged Jackson not to be distracted from the "battle against thirty-five millions of money [the Bank of the United States], against uncompromising nullification, against a scheme of protection, and of its correlative, waste by internal improvements." ${ }^{\text {134 }}$ Catron retained these Jacksonian connections while on the federal bench. He corresponded regularly with Presidents Jackson, Polk and Buchanan, ran the Van Buren presidential campaign in Tennessee and was one of Polk’s main campaign advisors. ${ }^{135}$ He is classified as a Jacksonian swing only because, as was the case with Wayne, no easily accessible public record exists of whether he thought the hated bank was unconstitutional (or constitutional).

Justices McKinley also straddles the border between a Jacksonian swing and hardliner. He began his career as a National Republican, but joined Jacksonian forces by 1826, though some contemporaries questioned whether his conversion was sincere. ${ }^{136}$ McKinley actively participated in the fight against the national bank in Congress, where he strongly supported the Jackson administration's effort to remove government deposits from Biddle’s institution, and the

${ }^{134}$ Gatell, “Catron,” p. 743.

135 See 6 Polk, pp. 3-5 (strategizing how to defeat the bank in 1842); Gatell, “Catron,” p. 743, 745; Roper, Thompson, p. 108.

${ }^{136}$ Frank Otto Gatell, “ John McKinley,” 1 The Justices of the United States Supreme Court, pp. 769-771; Jimmie Hicks, “Associate Justice John McKinley: A Sketch,” 18 The Alabama Review 227, 228-31 (1965). The probable sincerity of McKinley’s conversion to Jacksonianism during the late 1820s is discussed at length in Martin, "McKinley.” 
Alabama legislature, where he wrote a petition declaring that bank "inconsistent with our free institutions, and dangerous to the peace and safety of the union.”137 He condemned Marshall Court decisions by which "the powers of the Federal Government are, by mere construction, made to overshadow State powers, and render them almost contemptible,” and insisted that the national goernment exercise only those powers “expressly granted by the Constitution.”138 McKinley occasionally spoke out against internal improvements, once describing the system as “unjust and partial,",139 and insisted that "the United States cannot hold land in any State of the Union, except for the purposes enumerated in the Constitution.”140 Nevertheless, he also supported the Maysville Road Bill and vigorously urged the federal government to give the proceeds of the sale of public lands to the states. ${ }^{141}$ Still, at the time of his appointment to the

${ }^{137}$ Martin, “McKinley,” pp. 25-27; Gatell, “McKinley,” pp. 772-73.

${ }^{138}$ Martin, “McKinley,” pp. 9, 21 (quoting McKinley); Gatell, “John McKinley,” p. 770. More generally, McKinley appears to have accepted “(t)he compact theory of government,” and been “a true disciple of Thomas Jefferson, as Jefferson wrote in the Kentucky Resolution, and of the basic political philosophies of John C. Calhoun.” George C. Whatley, “Justice John McKinley,” 4 Bulletin of the North Alabama Historical Association 15, 17-18 (1959).

${ }^{139}$ Annals of Congress, $23^{\text {rd }}$ Cong., $1^{\text {st }}$ Sess., p. 429.

${ }^{140}$ Annals of Congress, $20^{\text {th }}$ Cong., 1 Sess., p. 507. See $20^{\text {th }}$ Cong., $1^{\text {st }}$ Sess., pp. 507-21.

${ }^{141}$ Annals of Congress, $21^{\text {st }}$ Cong., $1^{\text {st }}$ Sess., pp. 302, 340; $20^{\text {th }}$ Cong., $1^{\text {st }}$ Sess., p. 454 . See 
federal bench, he seems to have been considered an "orthodox, administration Democrat,"142 an acknowledged leader of the Jacksonian forces in Alabama, and a close associate of James K. Polk, the leader of Jacksonian forces in Congress. ${ }^{143}$ John Connor Campbell, at least, was under the impression that McKinley campaigned for the Senate in 1836, the year before his appointment, on a platform of constitutional opposition to the national bank, protective tariffs, and internal improvements. ${ }^{144}$

This survey of the Jacksonian swings provides much support for Webster's fear that

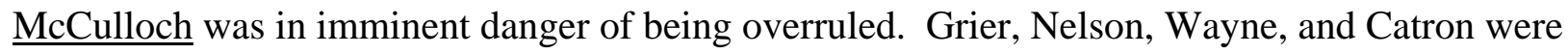
not classified as hardliners only because in 1999 no easily accessible public record exists of their declaring the national bank unconstitutional. The evidence that does exist, however, suggests that their contemporaries would have classified them with Clifford and Woodbury with respect to attitudes towards the American System. McKinley is best classified as a Jacksonian hardliner on the national bank, a swing on internal improvements, and a Whig on distribution. Campbell

Hicks, “McKinley,” p. 229; Gatell, “McKinley,” p. 772. McKinley did insist, however, that he supported the Maysville bill only because he was under instructions to do so from the Alabama state legislature. Martin, “McKinley,” pp. 17-18, 21.

${ }^{142}$ Gatell, “McKinley, p. 773. Jackson was apparently convinced that McKinley was sincere. See Abraham, Justices and Presidents, p. 104.

${ }^{143}$ Martin, “McKinley,” p. 30; Sellers, Polk: Jacksonian, p. 213.

144 See Saunders, Campbell, p. 31. 
is the only Jacksonian on whom the evidence of personal attitudes is conflicting. The evidence is clear, however, that he was becoming increasing opposed to most exercises of federal power at the time he was appointed to the Supreme Court.

\section{The Whigs}

The Taney Court could not be expected to adopt unanimously an anti-federal power position on the national bank and internal improvements for reasons that were both external and internal to the Jacksonian coalition. Jacksonian executives did not appoint all the justices who sat on the Supreme Court from 1836 until 1861. Justices Story and Thompson were appointed by National Republican executives. Justice Curtis was appointed by a Whig. The Taney Court after 1861 could be expected to demonstrate increased nationalist proclivities both as a consequence of three Lincoln judicial appointees and the very real fear that the Lincoln administration would ignore judicial decisions unduly limiting national power. Substitute Jeremiah Black for Noah Swayne, ${ }^{145}$ imagine a Congress willing to defend judicial power, and the Supreme Court during the Civil War probably would have declared unconstitutional Lincoln's imposition of the blockade that was, in fact, sustained by one vote in the Prize Cases. ${ }^{146}$

${ }^{145}$ Black’s nomination for the vacancy later filled by Swayne was defeated by one vote, only because most Southern Senators had previously resigned their seats. See Abraham, Justices and Presidents, pp. 115-16.

${ }^{146}$ FIND 
Whig strength on the Supreme Court was augmented by the extreme fluidity of American partisan coalitions during the first years of the second party system. Jackson's first two judicial appointees, Justices McLean and Baldwin, were appointed before political events led Jackson to define for himself and the nation the narrow construction of national power that would unite most Democrats during the late 1830s, 1840s and 1850s. ${ }^{147}$ As Daniel Feller and other historians note, Jackson’s “plans and policies were a mystery” when he first took office. ${ }^{148}$ Before Jackson's veto of the Maysville Road bill and national bank, many politicians, particularly in the Northwest, campaigning for Jackson as a friend of internal improvements. Prominent western Jacksonians in 1828 claimed to be better friends of internal improvements than Western supporters of John Quincy Adams. McLean and Baldwin were, thus, well within the Jacksonian mainstream when appointed to the Supreme Court. That they were no longer Jacksonians by 1836 was less a consequence of any change of position on their part, but the result of a greater clarification of the Jackson coalition as many (not all) proponents of the bank and internal improvements either adjusted their policy commitments or joined the Whig opposition. ${ }^{149}$ Only after the bank wars did Jackson highlight commitment to limiting national power when making judicial appointments. ${ }^{150}$

147 See Roper, Thompson, p. 105. 1 Warren 706-13 FIND.

${ }^{148}$ Feller, Democratic Promise, p. 161. See Feller, Democratic Promise, pp. 74, 161-62; Feller, Public Lands, pp. 90, 96, 103, 110.

${ }^{149}$ Feller, Democratic Promise, p. 186; Feller, Public Lands, pp. 141-42, 190-91.

${ }^{150}$ Abraham, Justices and Presidents, pp. 98-99. 
So understood, the McLean and Baldwin appointments highlight how alleged judicial mistakes often reflect the changed concerns of a political coalition, not marked differences in what was originally expected of a judicial appointee. Jacksonians later complained that Jackson bungled his first two appointments, ${ }^{151}$ but the better explanation, given the known proclivities of his nominees, was that Jackson had not yet firmly committed himself on constitutional issues before the bank War and Maysville Road veto. Justices McLean and Baldwin were known commodities in 1828. Baldwin, in particular, was recognized as a committed proponent of tariffs and internal improvements. Every politically active Jacksonian knew this. Baldwin's views remained the same when on the bench; the nature of the Jacksonian coalition changed.

The Baldwin and McLean nominations also highlight a point made earlier with respect to Taney Court decisionmaking in state cases, that politics may often better explain the parameters of judicial decisionmaking the dictate the precise content of particular judicial decisions. The nature of the Jacksonian coalition in 1828 did not practically guarantee the selection of justices with relatively broad understandings of federal power. Before nominating Baldwin, President Jackson was turned down by Senator William Smith of South Carolina, a vigorous opponent of the American System. ${ }^{152}$ Rather, the examination of politics explains Jacksonian appointees

\section{${ }^{151} 5$ Correspondence of Jackson,}

152 The McLean seat was originally slated to go to William Barry, who during the 1830s was a moderate opponent of the bank. Louis McLane of Delaware, a proponent of the bank, may have been nominated to the Supreme Court had President Jackson had another opportunity during his 
before 1832 (and Tyler appointees nominated when Tyler was mending fences with Whigs) could be sympathetic to federal power. Jackson during his first years in office considered appointing both known proponents and known opponents of federal power to regulate economic life because administration policy was not yet firmly settled on those matters. Political needs change over time, sometimes creating openings for certain kinds of justices, at other times practically foreclosing judicial options. Before 1830, attitudes on federal power varied more by region than by party. Westerners generally favored internal improvements and tariffs; southerners were generally opposed to both. After 1830, a political system began to form which increasingly privileged opponents of federal power for all judicial vacancies when Jacksonians were in office.

One consequence of Jackson's early travails and occasional Whig political successes was that five justices who sat on the Taney Court before the Civil War could be considered certain or almost certain votes to sustain most elements of the American plan, Joseph Story, Henry Baldwin, Smith Thompson, John McLean, and Benjamin Curtis. Joseph Story is the easiest vote to ascertain. He was a part of the unanimous court that upheld the national bank in McCulloch and then sent a note to President Monroe indicating that the court's opinion in the bank case absolutely committed them to sustaining federal power to make internal improvements. While purporting to be above partisan politics, Story admitted to generally voting a straight Whig ticket, frequently drafted nationalistic legislation for Whigs to introduce in Congress, and regarded the principles underlying McCulloch as of "fundamental importance to the existence of the 
government."153 At the end of the War of 1812, called on National Republicans to " extend the national authority over the whole extent of power given by the Constitution.” "Let us,” he declared,

have great military and naval schools; an adequate regular army; the broad foundations laid of a permanent navy; a national bank; a national system of bankruptcy; a great navigation act; a general survey of our ports, and appointments of port-wardens and pilots; Judicial Courts which shall embrace the whole constitutional powers; national notaries; public and national justices of the peace,

${ }^{153}$ William Wetmore Story, The Life and Letters of Joseph Story (Vol I) (Books for Libraries Press: Freeport, New York, 1971), p. 326 (quoting Joseph Story to Sarah Wetmore Story, March 17, 1819). See Swisher, Taney Period, pp. 114-15 (quoting Story to John McLean) (“my own belief is that a national bank is indispensable for the true and permanent interests of the Union”). For Story’s allegiance to the Whig party, see Story, 1 Life and Letters, pp. 424, 426, 538, 540; Swisher, Roger Taney, p. 430-31 (quoting Story to Clay, August 3, 1842) (“I am a Whig”). For Story’s career as a legislative draftsperson on such matters as federal common law, federal jurisdiction, admiralty, and bankruptcy, see Story, 1 Life and Letters, pp. 234, 246, 315, 437, 439; Story, 2 Life and Letters, pp. 268, 271-72; 292-96, 370-73, 402-408; Swisher, Taney Period, p. 43). Story also may have drafted the rendition procedures that were eventually incorporated into the Fugitive Slave Act of 1850. See R. Kent Newmyer, Supreme Court Justice Joseph Story: Statesman of the Old Republic (University of North Carolina Press: Chapel Hill, 1985), pp. 37677. 
for the commercial and national concerns of the United States. ${ }^{154}$

Whether Joseph Story would have shared Justice Robert Jackson's interpretation of McCulloch as sanctioned virtually any exercise is open to question. As Howard Gillman points out, Story and other antebellum jurists sympathetic to American System measures, neverthleless believed that most areas of economic life were reserved to the states. Nineteenth century Whigs should not be confused with New Dealers. Moreover, Story on circuit helped develop the equal footing doctrine, which, as will be discussed below, limited federal power over public lands in states. Still, on all questions of federal power in which Whigs differed from Jacksonians, Story could be found defending the exercise of federal power.

Justices Henry Baldwin, John McLean, and Benjamin Curtis could be counted on to support federal power to almost the same degree of certainty as Justice Story. Baldwin was a leading proponent of internal improvements and protective tariffs when in Congress. ${ }^{155}$ He

${ }^{154}$ Story, 1 Life and Letters, p. 254 (quoting Joseph Story to Nathaniel Williams, February 22, 1815). See Story, 1 Life and Letters, pp. 270-71, 296, 484-85; Story 2 Life and Letters, p. 82

${ }^{155}$ Flavia M. Taylor, "the Political and Civic Career of Henry Baldwin, 1799-1830," 24 Western Pennsylvania Historical Magazine 37, 45-49 (1941); Frank Otto Gatell, “Henry Baldwin,” The Justices of the United States Supreme Court 1789-1978: Their Lives and Major Opinions (Volume I) (edited by Leon Friedman and Fred L. Israel) (Chelsea House Publishers: New York, 1980), pp. 573-75; Roper, Thompson, p. 105; Abraham, Justices and Presidents, p. 98; Swisher, Roger Taney, pp. 181, 211, 311 (describing Baldwin as “a fanatical friend of the Bank”). 
publicly opposed Jackson's attempt to destroy the national bank, urged Taney to curtail the administration's attack on that institution, and joined the Whig opposition once it formed. ${ }^{156}$ Story, a reliable authority on Whig orthodoxy, thought "quite well of the [Baldwin] appointment."157

McLean in politics is best described as a "Madisonian Whig."158 McLean claimed "he had never voted an anti-Whig ticket,” and that “(n)o person in the United States desires more ardently than I do, the ascendancy of Whig principles generally."159 As a congressperson during the

${ }^{156}$ Gatell, “Baldwin,” pp. 576-77; Abraham, Justices and Presidents, p. 98.

${ }^{157}$ Story, 2 Life and Letters, p. 35 (quoting Joseph Story to Sarah Waldo Story). Daniel Webster was similarly pleased. See Swisher, Taney Period, p. 49. Baldwin later wrote a monograph sharply criticizing the views Story advocated in his Commentaries, but that work was entirely devoted to concerns whether state laws were constitutional. Henry Baldwin, A General View of the Origin and Nature of the Constitution and Government of the United States (Da Capo Press: New York, 1970). No evidence exists that Baldwin while on the Court modified his views on the national bank, internal improvements or the tariff.

${ }^{158}$ Veritas, A Sketch of the Life of John McLean of Ohio (Washington, 1846), p. 15. See Veritas, Sketch, pp. 6-7, 9.

${ }^{159}$ Francis P. Weisenburger, The Life of John McLean: A Politician on the United States Supreme Court (Da Capo Press: New York, 1971), p. 110 (quoting John McLean to John Teesdale, December 17, 1846); “Letters of John McLean to John Teesdale,” Bibliotheca Sacra (October 
1810s, he was a devotee of internal improvements and protective tariffs, as well as an opponent of John Randolph. An admiring biographer declared that McLean "has always sustained the great Whig cause and measures-has supported a Revenue Tariff, shaped for the protection of Home Industry; a well regulated system of Currency; and uniformly opposed the Sub-treasury,” the banking system favored by many Jacksonian Democrats. ${ }^{160}$ McLean did vote against the national bank in 1817, but by the 1840s made clear that he thought the constitutionality of that bank had been settled by McCulloch. ${ }^{161}$ Story regarded McLean as “a good and satisfactory appointment,” maintained "an intimate friendship" with him while they were on the bench, and was "warmly interested that [McLean] should become a candidate for the Presidency."162 Given McLean’s 1899), p. 720. See Weisenburger, McLean, p. 79-80 (indicating that by 1832 McLean was an “anti-Jackson man”).

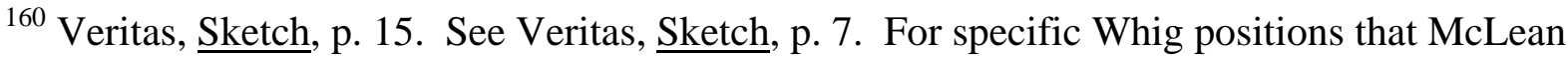
endorsed see Weisenburger, McLean, pp. 18, 33, 48-49, 75-76, 85, 108; “Letters of John McLean to John Teesdale,” p. 722.

161 “Letters of John McLean to John Teesdale,” p. 722 (“the question is undoubtedly settled as fully as it is possible to settle any question arising on the construction of the Constitution”). For McLean's general waffling on the bank issue, see Weisenburger, McLean, pp. 17, 93-95; "Letters of John McLean to John Teesdale,” pp. 721-22.

${ }^{162}$ Story, 1 Life and Letters, p. 564 (quoting Joseph Story to William Fettyplace, March 1829); Story, 2 Life and Letters, p. 35; Swisher, Roger Taney, p. 431 (quoting Story to McLean, October 
constant hunger for the presidency, one cannot rule out the possibility that he might have cast a vote against some aspect of the American plan under the right political conditions. ${ }^{163}$ Still, while McLean's past politics cannot rule out the possibility that he would have voted to declare specific details of the American plan unconstitutional, little doubt exists that his vote in most cases would have followed Justice Story.

Benjamin Curtis identified with conservative Whigs throughout his political career and “always voted for the candidate of the Whig party while that organization continued to exist.”164 Though specific records of his attitude towards the national bank do not seem to have survived, ${ }^{165}$ Curtis was a strong supporter of Daniel Webster, whom he praised for "the just and sound principles which you have always held and enforced “ on "the maintenance of a safe currency”(a probable reference to Webster's support of the national bank), and for being “a steady and 9, 1843).

163 See Roper, Thompson, p. 104 (noting McLean’s willing to “trim his principles” to advance his political career).

${ }^{164}$ George Ticknor Curtis, Memoir of Benjamin Robbins Curtis, LL.D. (Vol. I) (edited by Benjamin R. Curtis) (Little, Brown, and Company: Boston, 1879), p. 150. See Curtis, $1 \underline{\text { Curtis, }}$ pp. 114, 138, 180 (noting that Justice McLean “would be a good President”).

${ }^{165}$ After the Civil War, Curtis gave a speech implying the national government had the power to incorporate a bank. See George Ticknor Curtis, Memoir of Benjamin Robbins Curtis, LL.D. (Vol. II) (edited by Benjamin R. Curtis) (Little, Brown, and Company: Boston, 1879), p. 366 . 
powerful friend” of "the internal improvements of the whole United States."166 Curtis did strongly oppose the policies Lincoln adopted to fight the Civil War, most notably the emancipation proclamation and the suspension of habeas corpus. Before joining the bench, he asserted that " $(\mathrm{t})$ he question whether the Constitution of the United States gives the power to construct roads is an open and difficult one.”"167 Nevertheless, nothing in his antebellum record supports an inference that he would have declared Whig policies unconstitutional, and much indicates that he would have happily sustained such measures.

Justice Smith Thompson’s attitudes on the issues dividing Whigs from Jacksonians are more difficult to ascertain. Thompson's initial political associations were with leading New York anti-federalists and he formed a political alliance with Martin van Buren early in both of their careers. He was also a protégée of the conservative jurist James Kent, strongly identified with the more moderate wing of New York Republicanism during the 1810s, and a strong supporter of Adams against Jackson during the 1828 presidential election. ${ }^{168}$ Thompson's opinions on the

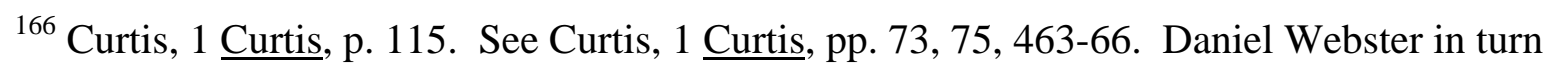
promoted Curtis when a Whig president had the opportunity to appoint a Supreme Court Justice. Curtis, 1 Curtis, p. 154. See Abraham, Justices and Presidents, pp. 110-111 (noting Curtis’s Whig credentials)

${ }^{167}$ Curtis, 2 Curtis, pp. 306-55, 116.

${ }^{168}$ For Thompson’s conflicting and changing political alliances, see Donald Malcolm Roper, $\underline{\text { Mr. }}$ Justice Thompson and the Constitution (Garland Publishing, Inc.: New York, 1987), pp . 1, 
New York bench indicate strong support for state incorporated banks, ${ }^{169}$ but the issue that divided Jacksonians from Whigs was the desirability of a national bank, not banking per se.

Unfortunately, as Thompson’s biographer acknowledges, on questions concerning “Hamiltonian programs,” “Thompson’s views ... were not specifically recorded.” ${ }^{170}$ Thompson concurred in a judicial decision condemning state power to interfere with the national bank his first year on the federal bench, but he had suggested a more narrow conception of federal power while on the New York bench. He later reaffirmed that narrow conception of federal power in his dissenting opinion in Brown v. Maryland. ${ }^{171}$ Perhaps the best that can be said of this sparse record is that Thompson probably would have sustained McCulloch, given his penchant for stare decisis, ${ }^{172}$ but might have joined a judicial majority declaring some forms of internal improvement unconstitutional. Donald Roper accurately sums up the available evidence when he declares

3, 10-14, 23; Gerald Dunne, "Smith Thompson," 1 The Justices of the United States Supreme Court, pp. 475-78, 485.

${ }^{169}$ Roper, Thompson, pp. 13-14.

${ }^{170}$ Roper, Thompson, p. 35. Roper does indicate a “similarity in the patterns of Thompson’s and Kent’s economic thought”). Roper, Thompson, p. 35. Story in 1807 thought Thompson had “the reputation of industry and soundness.” Story, 1 Life and Letters, p. 145 (quoting Joseph Story to Samuel P. P. Fay, May 18, 1807).

${ }^{171}$ Livingson v. Van Ingen, 9 Johnson Reports 507 (FIND); FIND. See Roper, Thompson, p. 142

172 See Roper, Thompson, p. 54; Dunne, “Thompson,” p. 484. 
“(w)hat Thompson would have done had he been faced with positive Congressional legislation is so far removed from the actual facts that it is hardly worth conjecture. For what it is worth, however, he probably would have upheld such laws.”"173 At least John Quincy Adams though Thompson a friend of the national bank. ${ }^{174}$

The Whigs on the Taney Court did not always favor national power on those issues that divided antebellum Jacksonians and their opponents. On some issues, judicial Whigs maintained that Jacksonians in power were acting unconstitutionality. Story complained of numerous constitutional violations during the Jackson presidency, most notably the way government deposits were removed from the national bank. ${ }^{175}$ He also wrote several pamphlets attacking Jacksonian claims that the federal government was constitutionally authorized to annex Texas. ${ }^{176}$ McLean publicly declared the Mexican war unconstitutional. ${ }^{177}$

Still, at no point after 1837 was there a Whig/proto-Whig majority on the Court that could be counted on to defend the bank and perhaps void some Jacksonian measure, even if Thompson is considered a Whig on all matters. Thompson died in 1843, Baldwin the next year, and Story

${ }^{173}$ Roper, Thompson, p. 296.

${ }^{174}$ See 8 Adams Memoirs 304; Swisher, Taney Period, p. 45.

${ }^{175}$ FIND

${ }^{176}$ FIND. See Swisher, Taney Period, p. 560.

17773 Niles 354 (1848). See Swisher, Taney Period, p. 564. 
the next year. Curtis was only on the bench from 1851 until 1857. Hence, during the twenty years before the Civil War, the Court would need at least one and on average three Jacksonian defectors in order for a judicial majority to sustain any element of the American plan. Virtually, all of the eleven possible defectors, however, were on record politically as opposing most elements of the American System. Many had explicitly declared such measures unconstitutional.

\section{The Attitudinal Scorecard and Judicial Decisionmaking}

If the justices are lined up in very rough order according to their attitudes on the national bank and internal improvements for the purpose of determining which justice would most likely have been in the judicial majority in a case raising the constitutionality of these American System proposals, ${ }^{178}$ the results are as follows. On the national bank, Catron would have been the most probable swing justice from 1837 until 1845, Wayne would have been the swing justice from 1846 until 1851, Grier (or Nelson) would have been the swing justice from 1852 until 1858, and Catron would have been the swing justice from 1859 until 1860. On distribution and any other matter McKinley thought constitutional, Thompson would have been the swing justice from 1837 until 1843, McLean (or another of the Whigs) would have been the swing justice in 1844 and

\footnotetext{
${ }^{178}$ My rough order, from most likely to least likely to declare American System measures constitutional, is Story, Baldwin, McLean, Curtis, Thompson, McKinley (on distribution and, possibly, internal improvements), Campbell, Nelson, Grier, Catron, Wayne, McKinley (on the national bank and, possibly internal improvements), Clifford, Woodbury, Taney, Barbour, Daniel.
} 
1845, Catron would have been the swing justice from 1846 until 1851, Grier (or Nelson) would have been the swing justice from 1852 until 1858, and Catron would have been the swing justice from 1859 until 1860. In short, the national bank throughout the Taney years and internal improvements after 1844 would have survived judicial scrutiny only if such measures were held constitutional by justices who were strong partisans of the party vigorously opposed to that measure and often by a justice who before joining the bench had led the political fight against such measures. The Supreme Court during the 1840s would have declared the national bank unconstitutional even if three partisan Jacksonians defected and voted to sustain that measure. ${ }^{179}$

Contemporary approaches to judicial decisionmaking offer three reasons that might explain why, despite the attitudes reflected in this scorecard, the Taney Court failed to narrow or overrule McCulloch. Proponents of the strategic model of judicial decisionmaking may suspect that crucial Jacksonians on the bench did not vote their policy preferences in some cases in order to avoid political reprisals. The Warren Court retreat during the late 1950 s is generally credited to that tribunal's desire to prevent the passage in Congress of proposals to curtail federal jurisdiction over numerous subjects. ${ }^{180}$ Perhaps Taney and others feared that a decision overruling

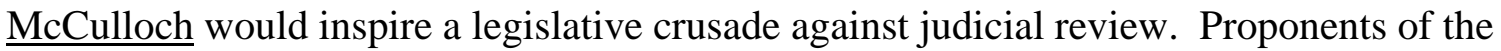

${ }^{179}$ Assuming Campbell was a secret Whig and always voted to sustain American System policies, the Jacksonian majority on all issues during the 1850s could stand one defection until 1858 and two defections until 1860.

${ }^{180}$ Murphy 
attitudinal model of judicial decisionmaking may suspect that crucial Jacksonian appointees changed their mind on the expedience, justice or constitutionality of some contested policy. Justice William Brennan clearly became more sympathetic to women's rights issues when on the Court. ${ }^{181}$ Perhaps Taney and others when on the bench abandoned their objections to the monster bank. Proponents of the legal model of judicial decisionmaking may suspect that the judicial role compelled Jacksonians on the bench to abandon partisan behaviors and articulate different sentiments then they previously uttered when engaged in legislative and electoral politics. Justice Felix Frankfurter insisted that justices were often obligated to sustain measures they would condemned as legislators. ${ }^{182}$ Perhaps Taney and others concluded that such legal considerations as precedent and deference to other institutions compelled them to be conscientious nonparticipants in the Bank War they helped initiated while in the elective branches of the government.

The strategic model of judicial decisionmaking clearly does not explain Taney Court decisionmaking from 1836 to 1860 . The model does perform wonderfully during the Civil War. The desperate desire to avoid a clash with the Lincoln administration best explains the gross misreading of the Judicial Act of 1787 the Taney Court majority proffered in Roosevelt v. Meyer ${ }^{183}$ to justify the decision to deny the jurisdiction necessary to decide the constitutionality of

\footnotetext{
${ }^{181}$ Compare Hoyt v. Florida FIND with Craig v. Boren, 429 U.S. 190 (1976).

${ }^{182}$ Barnette FIND

${ }^{183}$ FIND
} 
the Legal Tender Act of $1862 .{ }^{184}$ During the twenty-five years before the Civil War, however, the federal government was either partly or fully dominated by officials who desired a judicial decision limiting or overruling McCulloch. No evidence exists that any prominent Jacksonian or Whig would challenge judicial rulings substantially narrowing the scope of federal power over the national economy. When the Supreme Court in Dred Scott declared a federal law unconstitutional, that decision was strongly supported by the Buchanan administration.

The partisan behavior of most Taney Court justices while on the bench refutes the attitidunal suggestion that crucial Jacksonian justices became more sympathetic to Whig programs when on the bench and casts grave doubts on the legal hypothesis that the judicial role substantially constrained Taney Court behavior. Taney Court justices retained both their political commitments and partisan connections throughout their tenure on the bench. Few, if any, believed that their position on the court barred various efforts to give non-legal aid and comfort to

${ }^{184}$ Jurisdiction was denied on the ground that because the New York Court had sustained the Legal Tender Act, the Supreme Court could not hear the case under section 2 of the Judiciary Act, which provided jurisdiction only in cases where a state court declared a federal law unconstitutional. Counsel, however, properly maintained that the Supreme Court had jurisdiction under Section 3 of the Judiciary Act. That provision provided jurisdiction whenever a state court denied a claim based on the federal constitution, and the plaintiffs in the New York case had maintained that Article I, Section 9 of the Constitution gave them the right not to accept legal tender as payment for a preexisting debt. Significantly, a unanimous Court which included many members of the Roosevelt Court, immediately overruled that decision after the Civil War. FIND 
their political sponsors, as long as such aid and comfort was given somewhat discretely.

Supreme Court justices during the Taney years routinely engaged in the sort of partisan activism that contemporary jurists officially shun. Catron was particularly active in political affairs while on the Court. He helped manage Polk’s successful presidential campaign in 1844, and served as a trusted political advisor to Presidents Jackson, Polk and Buchanan. ${ }^{185}$ Chief Justice Taney corresponded regularly with Jacksonian presidents and consulted with President Van Buren on financial policy. ${ }^{186}$ Taney, Grier and Clifford while on the bench informed President Buchanan, his subordinates or political allies that crucial administration policies had

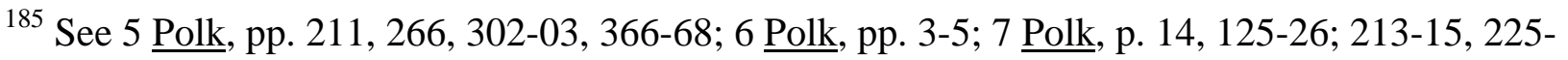
27, 356-57, 427, 430; 9 Polk p. 396. See Charles Grier Sellers, Jr., James K. Polk: Jacksonian 1795-1843 (Princeton University Press: Princeton, 1957), pp. 322, 350-51, 384, 400, 454-55; Charles Grier Sellers, Jr., James K. Polk: Continentalist 1843-46 (Princeton University Press: Princeton, 1966), pp. 5, 19-20; Swisher, Roger Taney, p. 438; Gass, “Catron,” p. 55, 58, 71. Catron may have written the portion of President Buchanan’s inaugural address that urged citizens to adhere to whatever rulings the Supreme Court made on the status of slavery in the territories. Swisher, Taney Period, pp. 617, 621.

${ }^{186}$ Swisher, Roger Taney, pp. 339-42, 344-45. Taney also continue to serve as Attorney General for almost a year after his nomination to the Chief Justiceship had been confirmed by the Senate. During this time, he advised President Jackson on constitutional issues and helped write the President’s farewell address. See Swisher, Roger Taney, pp. 326-337. 
their full support. ${ }^{187}$ After Polk was elected, Taney wrote him a letter declaring,

I feel so truly rejoiced at your election as President of the U. States, that I must indulge myself in the please of offering you my cordial congratulations. We have passed through no contest for the Presidency more important than the one just over; nor have I seen any one before in which so many dangerous influences were combined as were united in support of Mr. Clay. Your triumphant success gives me increased confidence in the intelligence firmness \& virtue of the American people; and in the safety and stability of the principles upon which our institutions are founded. ${ }^{188}$

Peter Daniel while on the bench continued to advise Democratic leaders and conservative

Virginia politicians. He publicly supported Martin van Buren’s presidential efforts in 1844. ${ }^{189}$

Joseph Story drafted Whig campaign documents and prominent legislation, including the

prototype for the Fugitive Slave Act of 1850. Grier vigorously supported the Fugitive Slave Act of 1850, publicly attacking opponents of that measure. ${ }^{190}$ John McLean used his judicial post as a

${ }^{187}$ See Swisher, Taney Period, p. 645 (quoting Taney to Franklin Pierce, August 29, 1857), 732-

33 (quoting Grier to J.S. Black, September 15, 1859 and Clifford to James Buchanan, July 19, 1859). See American Historical Review 359.

${ }^{188}$ Roger B. Taney to James K. Polk, 7 Polk, p. 338. See Swisher, Roger Taney, pp. 435-36, 457-

58, 554. Taney may have privately discussed the proper ruling in Dred Scott with Attorney

General Caleb Cushing. See Swisher, Taney Period, p. 620.

189 Swisher, Roger Taney, pp. 434-35; Frank, Daniel, p. 142. See Swisher, Roger Taney, p. 437-

38 (discussing Daniel to Van Buren, November 19, 1844), 478-79; Swisher, Taney Period, p. 400.

190 Swisher, Roger Taney, p. 482. Grier also publicly sided with Attorney General Jeremiah

Black in his debate with Stephen Douglas over the proper interpretation of Dred Scott. Swisher, 
springboard in his incessant campaigns for the presidency. Samuel Nelson and John Campbell were seriously considered for the Democratic party’s 1860 presidential nomination; ${ }^{191}$ Levi Woodbury also seems to have had presidential aspirations while on the Court. ${ }^{192}$ Campbell and Nelson played leading roles in efforts to bring about a compromise that would have prevented secession and the Civil War. ${ }^{193}$ Nelson personally met with prominent members of Lincoln’s cabinet to inform them that both he and Chief Justice Taney believed the president could not use force to coerce a state that had seceded from the Union. ${ }^{194}$ The Jay Court may have officially sworn off advisory opinions, ${ }^{195}$ but that precedent did not inhibit Justices Story, Daniel and Baldwin from responding to a Senate request for an analysis of federal bankruptcy law (Taney, Thompson and McLean largely refrained from passing judgment) or Justice Story from

Roger Taney, p. 535.

${ }^{191}$ Ronald Sklut, “John Archibald Campbell: A Study in Divided Loyalties,” 20 Alabama Lawyer 233, 244 (1959).

192 Swisher, Taney Period, p. 526.

193 Swisher, Roger Taney, pp. 537-38; Swisher, Taney Period, pp. 739-42; Sklut, “Campbell,” pp. 245-52.

${ }^{194}$ Swisher, Taney Period, p. 742.

${ }^{195}$ FIND 
submitting to the full court his proposals for expanding federal admiralty jurisdiction. ${ }^{196}$

These partisan activities seemingly deal a devastating blow to attitudinal models of judicial decisonmaking, at least as those models are applied to the Taney Court. Every political element required by scholars who think legal factors have almost no influence on judicial outputs is firmly in place. Jacksonian presidents had a common set of policies in mind when selected Supreme Court justices. All the evidence indicates that these presidents selected justices who were devoted to Jacksonian political causes. Indeed, the justices continued to play leadership roles in these causes while on the bench. All that is missing is what Jacksonian presidents and contemporary attitudinalists expect, a series of judicial decisions sharply limited the constitutional power of the federal government to regulate the economy.

This attitudinal debacle is an apparent cause for legalist celebration. A political regime makes a strenuous attempt to pack the judiciary with partisans committed to that regime's policy preferences. The justices in their off-the-bench activities demonstrate the most limited commitment to the separation of law and politics. Those very justices, however, seeming make a sharp separation between the two when deciding cases. A judiciary on public record as regarding a national bank, federal sponsored internal improvements and various distribution schemes as

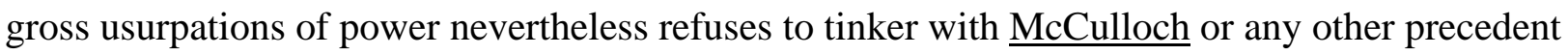
sanctioning such exercises of federal power. One can almost hear the cry "Hallelujah" echoed

\footnotetext{
${ }^{196}$ Swisher, Taney Period, pp. 138-42, 432.
} 
from the law schools (and a few political science departments). ${ }^{197}$

\section{Law and Jacksonian Politics}

If Supreme Court justices during the Taney years seemingly demonstrated a remarkable independence from their Jacksonian sponsors, the credit belongs primarily with the justices and not with antebellum politicians. Jacksonian politicians did not recognize law as an enterprise entirely distinct from politics. Political coalitions during the years before the Civil War consistently sought to pack the court with jurists sympathetic to their party's platform. No lawyer was deemed deserving of a seat on the federal bench solely by virtue of stellar legal qualifications. Rather, Jacksonians regarded past loyalty to Jacksonian political causes as the main virtue in a prospective judicial nominee. Indeed, Jacksonians in several respects made less of a separation between law and politics than political actors did after the Civil War.

One manifestation of the separation between law and politics is the general sense that the qualifications for political offices are different than the qualifications for judicial offices. A regime that respected this difference between law and politics would normally appoint to the Supreme Court persons whose previous career was primarily spent in law. The vast majority of justices appointed after the Civil War, in fact, had previously distinguished themselves primarily as law professors, lawyers or judges. President Truman and, to a lesser extent, President Franklin Roosevelt are the only executives over the last one-hundred and forty years who tended to

${ }^{197}$ See Kahn 
nominate to the Supreme Court persons with more experience in politics than law.

No general consensus existed before the Civil War that federal justices ought to have different backgrounds than politicians. While partisans from one party occasionally attacked an appointee from another party as a political hack, such objections went more to the nominee’s perceived constitutional politics than to partisan affiliation per se. Most Jacksonian appointees spent virtually all of their pre-judicial careers in electoral politics. McLean, Baldwin, Wayne, Taney, Clifford, McKinley, Woodbury, Barbour, Catron and Daniel had all earned national reputations in legislative and partisan politics before joining the federal bench. Grier and Nelson were the only two Taney Court justices who were best known as judges before their Supreme Court appointment. Nelson, just before joining the federal bench, had been the Democratic candidate for the Senate in New York. Curtis and Campbell were the only two Taney Court justices who were best known as lawyers before joining the Supreme Court. Campbell, just before joining the bench, had become a leading political spokesperson for southern rights. Many Taney Court justices are still known as much for their partisan political activities before and after their judicial service as for that judicial service. No member of the present Supreme Court may merit a biography for their non-judicial activities, ${ }^{198}$ but most biographies written of Taney Court justices spend as much time detailing their political activities as their legal activities.

If anything, judicial nominees without substantial political experience fared less well in the antebellum confirmation process. The judicial nominees the Senate rejected tended to have far more traditional legal backgrounds than either the nominees confirmed or the persons who

${ }^{198}$ Levinson, pp. 219-220. 
refused to be nominated. George W. Woodward, the only Jacksonian judicial nominee rejected by the full Senate, was one of only two Jacksonian judicial nominees with virtually no experience in electoral politics (the other was Grier). Of the eight other judicial nominees the Senate refused to confirm, only three had prominent political careers, Senator George Badger, Attorney General Jeremiah Black, and John Spencer. Black probably would have been confirmed had his nomination been sent to the Senate before the election of 1860 or even before many southern senators had resigned their seats. ${ }^{199}$ Three of the other rejected nominees were career judges, Reuben Walworth, Edward King, and John Meredith Read. The other two were career lawyers, William Micou and Edward Bradford. ${ }^{200}$ Every Jacksonian Democrat who turned down a presidential judicial nomination has a fairly substantial entry in the Dictionary of American Biography. Of the justices appointed, only Grier and possibly Nelson would have lacked an entry had they not been on the Supreme Court. Four of the nine rejected justices (King, Micou, Bradford and Woodward) have no biography. The Read and Walworth entries are substantially shorter than the biographies of the persons who rejected judicial nominations.

Whigs and orthodox Jacksonians had different notions of proper judicial qualifications. With the exception of Polk, Jacksonians always promoted seasoned politicians to the Supreme Court. Fillmore, the one orthodox Whig president who had the opportunity to make judicial

199 Abraham, Justices and Presidents, pp. 115-16.

200 See Gatell, “Samuel Nelson,” pp. 822-23; Abraham, Justices and Presidents, pp. 106-07, 109, 111-12, 115-16. 
appointments, consistently choose persons from more traditional legal backgrounds. ${ }^{201}$ Lincoln $^{2}$ also preferred professional lawyers and judges for filling associate judicial vacancies, though David Davis served as his political manager. ${ }^{202}$ Tyler’s nomination patterns are particularly interesting. Three of the four Democrats he strongly considered nominating to the Supreme Court, Buchanan, Wright, Van Buren, were career politicians. Nelson was the exception. By comparison, four of the six Whigs Tyler asked to join the Supreme Court, Horace Binney, Walworth, King, and Read, were career judges or lawyers. John Sergeant and Spencer are the exceptions, though they were not nearly as politically distinguished as Buchanan, Van Buren and Wright. Significantly, the practice of emphasizing the legal credentials of potential justices was institutionalized only after the Civil war, when the executive department was generally controlled by ex-Whigs.

Respect for the separation of law and politics may also be manifested by a general understanding that justices should not engage in ordinary partisan behaviors. Americans at the dawn of the twenty-first century expect that Supreme Court justices will not campaign for elected offices, will not assist in campaigns for elected offices even to the extent of merely making their voting preferences known, or actively participate in any legislative matter that does not directly

${ }^{201}$ Fillmore asked Curtis, Bradford, Micou, and Judah Benjamin to accept a nomination to the Supreme Court. Benjamin is now best known for his political activities. He had never held political office, however, when asked by Fillmore to fill a Supreme Court vacancy.

${ }^{202}$ Lincoln did choose a career politician, Salmon Chase, for the Chief Justiceship. 
involve judicial procedure. These canons of judicial behavior are often honored in the breach. ${ }^{203}$ Still, no member of the present Supreme Court is publicly known to be engaging in any of these prescribed activities.

No general consensus existed before the Civil War that federal justices ought to fully remove themselves from partisan activities. Although the judicial role was generally understood as requiring a certain discreteness, Jacksonian and Whig Supreme Court justices routinely socialized with leading politicians, many of whom were also members of the Supreme Court bar. $^{204}$ Taney Court justices regularly corresponded on political issues and strategy with partisan leaders, as well as engaging in other political activities that would violate numerous contemporary canons of judicial ethics. ${ }^{205}$ Scattered complaints aside, the antebellum polity did not consider unethical Justice McLean's efforts to run for the presidency while on the Court or Justice Catron's managing presidential campaigns from the bench. “Don’t believe that I have any squeamishness on the Judgeship score,” Catron informed James K. Polk during the 1844 campaign. “One of my brethren is openly seeking the Presidency, \& founds himself on this ground as a Judge, and is praised for his patriotism.”206

203 See especially, Bruce Murphy.

${ }^{204}$ See generally, Swisher, Roger Taney, p. 426 (noting the numerous reasons why Taney Court justices were “deeply interested” in partisan affairs), 449-50.

${ }^{205}$ See pp. __ , above.

${ }^{206}$ John Catron to James K. Polk, FIND, 7 Polk, p. 383. 
These blurring of the lines between law and politics do not demonstrate that Jacksonian politicians understood law as mere partisan politics. Several elements of judicial politics during the second party system demonstrate an understanding that judicial politics was a distinctive activity, different in important respects from electoral, legislative or other forms of politics. Most obviously, Jacksonians sought to place on the court justices who would articulate Jacksonian legal and constitutional understandings. No expectation existed that the Taney Court would perform other needed services for the Jacksonian coalition. Supreme Court appointments were not made for the purpose of improving the party newspaper, mobilizing more voters, or developing a military strategy against Mexico. Jacksonians understood the Supreme Court as a legal institution, an institution suited only to advance the legal aspirations of their political coalitions. Other dimensions of politics were dealt with by other political institutions.

Jacksonians also scrupulously adhered to legal rules and legal understandings when staffing the Supreme Court. Whig justices were never pressured to resign or threatened with personal harm should they fail to do the administration's will. At most, Jacksonians threatened not to enforce adverse judicial decisions, a practice they believed could be justified legally. All judicial nominees were vetted by the Senate. No Jacksonian ever suggested that a nominee who did not obtain the required vote could nevertheless sit on the court. These practices may seem obvious, but regimes that do not respect the difference between law and politics do not play according to the rules when staffing their judicial systems.

Indeed, the practice of staffing the court with Jacksonian sympathizers hardly demonstrates a desire to reduce constitutional law to mere partisan politics. Jacksonians wanted good and virtuous justices. Like many people, they regarded as proof of one’s legal virtue 
evidence that a prospective jurist shared their constitutional vision. That Americans at the dawn of the twentieth century may think that one could not reach Jacksonian constitutional conclusions on purely legal grounds does not change that fact that Jacksonians thought they were engaged in constitutional politics of the highest sort. Jacksonians during the Taney years exhibited a fairly robust commitment to reducing the power of the federal government over the national economy. The public messages of Jacksonian presidents, their use of the veto power, and their judicial nominations after 1830 exhibit a consistency on certain constitutional questions that would do a court proud. Why should we insist on claiming that a political coalition that runs on the same platform for twenty years is engaging in mere politics when a court that demonstrated the same consistency would be hailed for its commitment to neutral principles of constitutional law. 
